\title{
Legal Project Management: Projectifying the Legal Profession
}

\author{
Justine Rogers \\ University of New South Wales, Australia \\ Peter Dombkins \\ PwC Australia and University of New South Wales, Australia \\ Felicity Bell \\ University of New South Wales, Australia
}

\begin{abstract}
Post-Global Financial Crisis, global law firms and in-house departments have started to take up 'Legal Project Management' (LPM). LPM adopts and adapts project management methods for the law context as a means of streamlining, planning and costing legal work. This article examines LPM as an aspiring driver of managerialist change within the legal profession. In its reframing of all legal matters as 'projects', LPM is also an example of a more specific type of managerialist change, 'projectification': the process by which work activities, and our activities generally, are being organised and shaped as projects or temporary endeavours. Though we know managerialism is occurring, our understanding of how it manifests in, and is promoted by, specific practices and discourses within the workplace organisation is under-developed in the law context. It may be tempting to read managerialism as sullying traditional professionalism. But an extensive body of literature has documented the interactions of professional and managerial imperatives that result in what has been described as a hybridisation of different logics or belief systems. This article adds vital detail to the existing literature about managerialism within the legal profession by looking closely at LPM as projectification. To do so, it utilises Mirko Noordegraaf's three dimensions of professionalism that represent core points of distinction: coordination of work, authority or the grounds for legitimacy, and values at stake. Through these facets, it analyses LPM's somewhat contradictory aspects, illustrating the schismatic nature of projectification as both exciting and empowering, and ethically risky and dehumanising.
\end{abstract}

Keywords: Legal Project Management; managerialism; projectification; hybrid professionalism; law firms; professional organisations.

\section{Part I: Introduction}

Legal practices are under immense pressure to prove their 'value proposition' within an increasingly competitive environment. A number have introduced Legal Project Management (LPM) as a way in which to do so. This article represents the first indepth academic investigation of LPM as an aspiring driver of managerialist change within the legal profession and as an example of a more specific type of managerialist change, 'projectification'. Managerialism refers to the beliefs and methods of managers to influence and evaluate how people work. ${ }^{1}$ In the legal context, the 'managed professional business' describes the (archetypal) firm that has shifted from the traditional partnership (or sole practice) model to 'a more centralised and consciously

This research was carried out as part, and with the financial support, of the Law Society of New South Wales' Future of Law and Innovation in the Legal Profession (flip) research stream at UNSW Law, of which Dr Justine Rogers is Deputy-Director and Dr Felicity Bell is the Research Fellow. Peter Dombkins is Director, NewLaw at PwC Australia and is an Adjunct Associate Professor at UNSW Law. With the Law Society of New South Wales, the authors also thank Sharon Mo and Deborah Hartstein for their research assistance and the two anonymous reviewers for their instructive comments.

${ }^{1}$ Kirkpatrick, The New Managerialism, 43-44.

Except where otherwise noted, content in this journal is licensed under a Creative Commons Attribution 4.0 International Licence. As an open access journal, articles are free to use with proper attribution. ISSN: 2652-4074 (Online) 
coordinated organization'2 where expertise is deployed less to 'public-interest activities' ${ }^{3}$ than to furthering the 'efficiency of the firm and its value-added provision of a service'. ${ }^{4}$ Projectification is the process by which work activities, and our activities generally, are being organised and shaped as projects ${ }^{5}$ or temporary endeavours ${ }^{6}$ and temporary modes of organising. ${ }^{7}$ Both managerialism and projectification are technologies often used by leaders in organisations such as law firms to increase the use of other information technology and automated technologies.

This article aims to introduce and contextualise LPM as a new, 'projectifying' form of managerialism and examine its main features. It contributes to a core academic inquiry: what managerialism means for professionalism. More specifically, this study investigates whether managerialism has a 'contaminating' effect on, or 'competitive' presence for, professionalism (or practitioners' autonomy, ethics and expertise ${ }^{8}$ ) or whether, as some argue, it is or can be intrinsic to or supportive of 'traditional' professionalism, or even improves it. ${ }^{9}$ Similarly, scholars have asked which 'almost contradictory features' ${ }^{10}$ of projectification are more meaningful: those supporting innovation and flexibility, or those acting to control and standardise. ${ }^{11}$ These types of investigations inform wider discussions about the workings of professional change and the meanings of professionalism. Studies have shown, for instance, how professional change is occurring in a process of sedimentation, ${ }^{12}$ where there is a layering of different, co-existing values, varied across contexts. ${ }^{13}$ Different, oppositional and supportive professional 'logics' or belief systems ${ }^{14}$ are thus advanced, including now, projectification. These logics and their blends (or not) then shape and reinforce professionalism itself. We know managerialism is occurring in law, ${ }^{15}$ but we know little about projectification, the practices and discourses it promotes and its broader implications. This article looks closely at LPM as projectification.

We define LPM as the adaptation of project management methods: ${ }^{16}$ for strategising, planning, costing, tracking and reporting upon legal work; within agreed constraints, involving teams; and that capture data and feedback to improve future performance. ${ }^{17}$ LPM draws on and reworks the discipline of project management for a legal context. It is typically used in legal organisations to encompass 'matter management' ${ }^{18}$ and 'case management'; ${ }^{19}$ it frames all legal work as projects. LPM is a new, unsettled discipline whose primary, ostensible objectives are explicitly managerialist - to improve the effective and efficient performance of lawyers in providing legal services. ${ }^{20}$

\footnotetext{
2 Pinnington, "Archetype Change," 87.

${ }^{3}$ We note that professions, including law, have been commercial entities since their inception, and their public interest goals have been both part of classical theorising, and their self-definitions and public representations as much as enacted in practice. For a fuller discussion, see: Muzio and Flood, "Entrepreneurship, managerialism and professionalism".

${ }^{4}$ Pinnington, "Archetype Change," 86-87 (emphasis added).

5 Jensen, "The Projectification of Everything: Projects as a Human Condition."

${ }^{6}$ Project Management Institute, PMBoK Guide, 4-5, 10.

${ }^{7}$ Hodgson, Introduction, 1.

${ }^{8}$ Goodrick, "Constellations of Institutional Logics;" Blomgren, “Coping with Contradictions;” Noordegraaf, Public Management; Lander, "Drift or Alignment?"

${ }^{9}$ Noordegraaf, Public Management; Blomgren, "Coping with Contradictions;” Kirkpatrick, "Hybrid Professionalism;" Olakivi, "Rethinking Managerialism."

${ }^{10}$ Fred, "Local Government Projectification," 357.

${ }^{11}$ Fred, "Local Government Projectification," 357.

12 Cooper, "Sedimentation and transformation."

${ }^{13}$ Though see Pinnington and Morris's 2003 study: Pinnington, “Archetype Change," 95-97.

${ }^{14}$ Logics are belief systems that then absorb into guidance for practice action, identities, structures and norms: Canning, "Regulation and Governance," 171.

${ }^{15}$ A few examples include Sommerlad, "New Public Management in the Legal Aid Sector" (new public management), Campbell, "Salaried Lawyers" (billable hour); Empson, "Institutional Work Dyads" (partnership model), Muzio, "Consequences of Defensive Professionalism" (elongated hierarchies to protect partnership rewards).

${ }^{16}$ The tools and techniques applied to 'project activities to meet project requirements': Project Management Institute, PMBoK Guide, 4-5, 10.

${ }^{17}$ As this article demonstrates, this definition is by no means settled or agreed upon among legal project managers, and we recognise that defining LPM is also an act of professionalising for LPM. Lambreth (a practitioner) defines LPM as: 'the defining, planning, executing and evaluating of legal matters to meet the client's and firm's desired objectives and expectations (typically including budget) ... It is fundamentally about a more proactive, disciplined approach to managing your existing work to enhance the likelihood of meeting client and firm expectations': Lambreth, Legal Project Management, 1. See also Woldow, Legal Project Management in One Hour, 1. Our definition expands upon that provided by Woldow to also include strategy, costing, teams and data.

${ }^{18}$ A 'matter' is broadly defined as including all forms of both litigious ('case') and non-litigious legal work: Burton, Legal Thesaurus, 992.

${ }^{19}$ Case management and matter management refer to the processes used by lawyers to initiate and track the delivery of legal services.

${ }^{20}$ Woldow, Legal Project Management in One Hour, 1.
} 
LPM arose in the post-Global Financial Crisis era in response to clients' increasing demands of their law firms. First adopted by large firms in the United States, it has spread to their United Kingdom and Australian counterparts ${ }^{21}$ as well as to other types of legal practices. Other conditions have helped; for instance, by the 2000s, non-lawyer management specialists had become a common feature of large corporate law firms. ${ }^{22}$ Professional workplaces are now run using 'mixed management': practitioners who have moved into purely management roles or combine legal practice with management, and 'professional' managers from the outside, who may have trained in management and/or be members of management associations. ${ }^{23}$ Highlighting the timeliness of this article, project management now widely features as a component of the 't-shaped'24 and 'delta-shaped'25 lawyer: the archetype lawyer touted by industry and associations as the ideal, 'in-demand' practitioner who possesses traditional black-letter law competencies as well as 'new' skills including LPM. Some law schools and professional training courses are introducing elements of LPM into their content, as well as providing distinct LPM offerings.

To examine LPM, we adopt Professor of Public Management, ${ }^{26}$ Mirko Noordegraaf's, three dimensions of professionalism that represent core distinctions: coordination of work, authority or the grounds for legitimacy, and the values at stake. ${ }^{27}$ Through these facets, we analyse LPM's somewhat contradictory aspects, illustrating the schismatic nature of projectification as both exciting and dynamic, and controlling and efficient. LPM's orientation towards the client could be regarded as supporting the lawyer's traditional professional role as fiduciary. Yet, LPM's focus on proving a 'value proposition' 28 also expedites a discursive change from the lawyer as a trusted advisor to an accountable service provider. ${ }^{29}$ Meanwhile, LPM practitioners, responsible for introducing this expertise, do so in workplaces where they are often now employees, not just consultants. Therefore, LPM cannot be an instrument solely for the benefit of the ('demanding') client. Its other managerialist goals include to differentiate lawyers and firms within a competitive legal services market and to ensure they 'continuously improve' and remain profitable businesses, ${ }^{30}$ including by its structured approach to streamlining and coordinating legal work. Noting lawyers' typical scepticism towards management and non-lawyer management especially, ${ }^{31}$ LPM must be internally useful and acceptable to practising lawyers themselves. Besides accepted goals of managerialism such as efficiency and profit, ${ }^{32}$ proponents of LPM also advance LPM as a method to support satisfying working lives among lawyers. They claim it fills certain gaps within traditional firms, including through its emphasis on thriving teams and mentoring, clear and effective delegation, reduced risks and associated stress, ethical billing practices and better relationships among colleagues and with the client. $^{33}$

In Part II, we theorise managerialism within the legal profession to show the enabling conditions for LPM at the professional and organisation levels. We map out the sorts of indicators we might use to characterise and assess LPM as either an 'encroachment" ${ }^{34}$ and/or a welcome means of coordinating professional lawyers and their work, where managing or organising is a normal part of professional life. ${ }^{35}$ In Part III, we turn to projectification as our case example of managerialism, detailing the history of project management and its emergence as LPM. We set up what is at stake with LPM's arrival, highlighting the features of projectification, which assist our later analysis. Part III also provides our and others' statistical research into legal practice management and managers to give some sense of the numbers of practitioners, at least across Australia, the US and the UK, and to indicate its uptake in law practices. Part IV then examines LPM across Noordegraaf's three dimensions of professionalism: coordination of work, authority or the grounds for legitimacy, and values at stake. Part V discusses what LPM

\footnotetext{
${ }^{21}$ Cohen, "Reluctant Rise."

${ }^{22}$ Galanter, "Elastic Tournament," 1875-1876.

${ }^{23}$ Noordegraaf, Public Management; Blomgren, "Coping with Contradictions;" Muzio, "Towards Corporate Professionalization."

${ }^{24}$ Smathers, "21st-Century T-shaped Lawyer," 36.

${ }^{25}$ Runyon, "Delta Model Update."

${ }^{26}$ At Utretcht School of Governance.

27 Noordegraaf, "Hybrid Professionalism and Beyond," 188-89. There are, of course, other, well-established ways of conceiving professionalism that relate to Noordegraaf's scheme. For instance, as a distinct way of organising labour in society, with the focus on the power relations between producer and consumer of professional services (Johnson, Professions and Power) or as a 'project' to translate professional resources (special knowledge and skill) into financial and status rewards, and to protect them (Larson, The Rise of Professionalism). Some recent writers have recognised, or reminded us, that professions comprise purposive actors who struggle for jurisdiction and interact and exchange with other 'actors' in defining their expertise and boundaries. Professions have, thus, a processual, fluid nature (e.g., Liu, "Boundaries and Professions").

${ }^{28}$ Konstantinou, "Professionalism in Project Management," 31.

${ }^{29}$ Noordegraaf, "Hybrid Professionalism and Beyond," 190.

${ }^{30}$ Linton, "Maximising the Benefits."

${ }^{31}$ Empson, "Institutional Work Dyads," 835. Pinnington and Morris noted that of all professional practices, law firms were seen as the most resistant to change and the most likely to retain traditional arrangements at their core. Pinnington, "Archetype Change," 95.

32 Kirkpatrick, "New Managerialism," 64.

${ }^{33}$ We discuss the positive potential of LPM in our Part IV analysis.

${ }^{34}$ Noordegraaf, "Hybrid Professionalism and Beyond," 187, 190.

${ }^{35}$ Noordegraaf, "Hybrid Professionalism and Beyond," 202.
} 
reveals about managerialism within the profession and how projectification represents a new form of centralised control, but also possibilities for teamwork and transparency.

\section{Part II: Managerialism and the Legal Profession}

LPM fits into a wider emergence of managerialism within the legal and other professions. A rich scholarship shows how, for the past few decades, there has been a shift in emphasis ${ }^{36}$ away from 'professional' $\operatorname{logics}^{37}$ (where the autonomous, publiclyminded professional uses their special expertise to look after the individual, vulnerable client ${ }^{38}$ in a customised and ethical manner, ${ }^{39}$ working 'in relative isolation, ${ }^{40}$ ) towards 'managerial' (organised, managed action) ${ }^{41}$ and 'entrepreneurial' (commercialistic and innovative) forms in Australia and abroad. ${ }^{42}$ Adopting Noordegraaf's scheme from his study of the meanings of contemporary professionalism, 'professional' logics are found in workplace arrangements and work processes (how work is coordinated), the relationship dynamics (including who has authority and on what basis), and the values that are at stake. ${ }^{43}$

A variety of external economic, social, cultural, technological and demographic pressures have created or accelerated these shifts across a range of professions. ${ }^{44}$ These pressures have been summed up as the "deregulation of professional markets, increased competition, financial constraints, cost pressures, changes in government policy, globalisation, demands of international clients, increasingly sophisticated clients and technological change' ${ }^{45}$ They represent a set of mutually reinforcing "enabling conditions" ${ }^{46}$ for the emergence of a range of managerial practices and beliefs across the professions, including LPM. ${ }^{47}$ Such managerial practices started in private practice, in commercial settings, but are now found in the public and nonprofit sectors too ${ }^{48}$ Meanwhile, professional organisations have responded to and intensified these changes by drawing on subdisciplines of management ${ }^{49}$ such as marketing, consulting and human resource management, and less well-established domains like project management. The ongoing result is what has been called a 'hybridisation' of these (professional, managerial and so on) logics, where professional organisations 'heedfully seek out combinations of practices' to reach their desired outcomes. ${ }^{50}$ Noordegraaf says that scholars and practitioners have tended to see and treat managerialism as an undesired 'intrusion' that must be either resisted or bent to serve and protect professionalism. ${ }^{51}$ Yet, organisational arrangements, grounded in different logics, can be and are in practice more or less competitive or well-aligned with each other, with multiple possible meanings. ${ }^{52}$

Turning to the legal profession, until the late $19^{\text {th }}$ century, lawyers typically worked as solo or small-practitioner firms, with apprenticeship reflecting the extent of any hierarchical structure. ${ }^{53}$ The 'morally responsible' and specially skilled professional community was seen as inconsistent with or opposed to (and thus entitled to state protection from) the competitive or efficient market imperatives of the corporate form. ${ }^{54}$ The power within practices rested with professional experts, reflecting a belief that managerial and professional values were 'inherently incompatible' ${ }^{55}$ At the same time, a 'pure' conception of professionalism, and the institutions of professional self-regulation and professional identity built on that conception, relied on and reinforced a view of 'professional' work as being limited to a specified realm of knowledge that did not include other disciplines, including

\footnotetext{
${ }^{36}$ As mentioned, 'traditional' professions have always been businesses pursuing entrepreneurial activity: Sugarman, "Simple Images and Complex Realities."

${ }^{37}$ Reflecting broader rationalisation at the societal level: Bévort, "Scripting Professional Identities," 18.

${ }^{38}$ Noordegraaf, "Hybrid Professionalism and Beyond," 187.

${ }^{39}$ Lander, "Drift or Alignment?" 125.

${ }^{40}$ Noordegraaf, "Hybrid Professionalism and Beyond," 190.

${ }^{41}$ Noordegraaf, "Hybrid Professionalism and Beyond," 191.

${ }^{42}$ Pinnington, "Archetype Change;" Brock, “Archetypal Change;” Bévort, "Human Resource Management;" Noordegraaf, "Hybrid Professionalism and Beyond;" Weisbrot, "The Changing Face;" Daly, "Changes in Solicitors' Firms and Work."

${ }^{43}$ Noordegraaf, "Hybrid Professionalism and Beyond," 188-190; see also Gustafsson, "Professionals, Clients;" Hazard, "Regulatory Controls on Large Law Firms;" Woldow, "Why LPM Is Here to Stay."

44 Noordegraaf, "Hybrid Professionalism and Beyond," 196.

45 Brock, "Archetypal Change," 227.

46 Battilana, "How Actors Change Institutions."

${ }^{47}$ Cohen, "Reluctant Rise."

48 Noordegraaf, "Hybrid Professionalism and Beyond," 191; For a discussion of 'hybridity' in the public sector, see Olakivi, "Rethinking Managerialism."

49 Muzio, "Towards Corporate Professionalization."

${ }^{50}$ Lander, "Drift or Alignment?" 124.

${ }^{51}$ Noordegraaf, "Hybrid Professionalism and Beyond," 187-88.

${ }^{52}$ Lander, "Drift or Alignment?"

${ }^{53}$ Hazard, "Regulatory Controls on Large Law Firms," 594-95.

${ }^{54}$ Championed by Durkheim (1957) and Parsons (1954): Rogers, "Large Professional Service Firm,” 225.

55 Brock, "Understanding Professionals and their Workplaces," 5.
} 
managerial methods or expertise. ${ }^{56}$ In the ' $\mathrm{P}^{2}$ ' partnership, 'professionals were at once the operators, managers, and owners of the firm'. ${ }^{7}$

Nevertheless, managers began to appear. Mendelsohn and Lippman described, in the late 1970s, how Australian law firms had, in the 1950s, developed 'awareness of the need for efficiency', sometimes appointing (relatively minimally tasked) office managers and setting billing targets while both specialising and expanding, eventually becoming 'large, and to some extent bureaucratic, organisations' with a 'growing awareness of the need for organisational efficiency'. ${ }^{58}$ Though at first, the traditional partnership model organisation persisted, by the late 1960s these firms had grown to the extent that management by a single senior partner was becoming untenable. ${ }^{59}$ They began appointing 'managing partners' or specially qualified office managers, bureaucratising billing practices and otherwise quantifying work, investing in technology to improve efficiency while reducing support staff numbers and deconstructing matters into their specialised components for streamlined teamwork. ${ }^{60}$ These trends continued throughout the 1980s in Australia ${ }^{61}$ and abroad, with large firms increasingly restructuring in pursuit of economies of scale, economies of scope (becoming 'one-stop shop' legal service solutions) and diversification (maintaining multiple practice teams to subsidise each other in high- and low-profit periods) ${ }^{62}$ and requiring ever more business and management expertise to realise their international aspirations. ${ }^{63}$ Intense change within law practices has been enabled and spurred too by a political agenda of financial deregulation, macro-economic reform and global competition over the last four decades. ${ }^{64}$ The rise of 'new public management' means this has been felt in the public legal sector too, with an added emphasis on quality control structures and auditing. ${ }^{65}$ Moreover, consumer protection reforms to professional regulation over the past decades have contributed to a general re-conception of clients as 'consumers' ${ }^{66}$

A critical driver of managerialism that has dramatically increased in parallel to the changes just described is the corporate client becoming more demanding and the lawyer-client relationship drastically changing: 'legal clients are demanding greater control, predictability, accountability, and responsiveness from their outside legal service providers' ${ }^{67}$ Clients are increasingly able to 'shop around' for legal work, ${ }^{68}$ requesting alternative fee structures and greater justification of costs. ${ }^{69}$ Large firms, dealing with increasingly 'legally sophisticated' entity clients, are 'regulated' to a growing extent by the need to serve their clients' precise, complex and long-term legal needs. ${ }^{70}$ Through interviews with lawyers about promotion to partnership, Gustafsson and colleagues have shown how clients' direct power over lawyers' career progressions can reconstitute 'professional work' on an individual level, effectively tying business values to, and making them a key component of, an individual professional's 'success'. ${ }^{71}$ This microlevel alteration of practice and discourse reinforces broader shifts at the field level. ${ }^{72}$

In 2008, the GFC's 'perfect storm' of economic, regulatory and technological crises ${ }^{73}$ suggested real change was needed if legal practices were to survive. Indicators included the high-profile failure of several large US-headquartered law firms, notably including Heller Ehrman in 2008, Howrey in 2011 and Dewey \& LeBoeuf in 2012. At this time, Richard Susskind's influential (and indicatively entitled) book, The End of Lawyers?, was published ${ }^{74}$ and the US Association of Corporate Counsel's 'Value Challenge' was launched, ${ }^{75}$ providing visible indicators of a shift in the legal profession's mindset towards managerialism.

\footnotetext{
${ }^{56}$ Noordegraaf, "From 'Pure' to 'Hybrid'."

${ }^{57}$ Brock, "Understanding Professionals and their Workplaces," 5, citing Greenwood, "Ownership and Performance." $\mathrm{P}^{2}$ refers to large 'professional partnerships', coined by Greenwood, Hinings and Brown: see Greenwood, " ${ }^{2}$-form' Strategic Management."

${ }^{58}$ Mendelsohn "Corporate Law Firm in Australia," 82-3.

${ }^{59}$ Mendelsohn "Corporate Law Firm in Australia," 94-95.

${ }^{60}$ Mendelsohn "Corporate Law Firm in Australia," 94-95.

${ }^{61}$ Weisbrot "The Changing Face;" Daly, "Changes in Solicitors' Firms and Work."

${ }^{62}$ Samuelson, "The Organizational Structure."

${ }^{63}$ Empson, "Institutional Work Dyads."

${ }^{64}$ Shinnick, "Aspects of Regulatory Reform;” Rogers, "Large Professional Service Firm."

${ }^{65}$ Sommerlad, "Managerialism and the Legal Profession;" Sommerlad, "New Public Management in the Legal Aid Sector;" Kirkpatrick, The New Managerialism.

${ }^{66}$ Boon, "Regulation of Lawyers;" Shinnick, "Aspects of Regulatory Reform."

${ }^{67}$ Woldow, Legal Project Management in One Hour, viii.

${ }^{68}$ Bell, "Artificial Intelligence and Lawyer Wellbeing," 250; Woldow, "A Trend at the Tipping Point;" McGinnis, "Great Disruption,” 3054.

${ }^{69}$ Ruhl, "The rise of legal project management," 6.

${ }^{70}$ Hazard, "Regulatory Controls," 598-9.

${ }^{71}$ Gustafsson, "Professionals, Clients." For an analysis of how these dramatic changes are reflected in the HR strategies of large commercial law firms, as varied rationalities and discourses, see Sommerlad, "The Commercialisation of Law."

72 Evetts, "Sociology of Professional Groups."

${ }^{73}$ Cohen, "Reluctant Rise."

${ }^{74}$ Susskind, End of Lawyers?

75 Moynihan, "Taking Charge of Legal Spending."
} 
Moreover, in-house legal practice, defined by fidelity to a single entity client, has grown more prevalent. ${ }^{76}$ In-house teams have become 'expert purchasers of legal services' from external providers, ${ }^{77}$ including, increasingly, global firms offering cheaper services via massive economies of scale, offshore outsourcing services from lower-cost countries ${ }^{78}$ and/or onshoring, where the lower status work is done in satellite offices outside city centres. ${ }^{79}$ More recently, competition for market share and talent among firms has been intensified by the emergence of 'NewLaw' providers, particularly for 'commoditised' tasks or routinised processes such as standardised document services ${ }^{80}$ and contractual remediation, and 'LegalTech' firms, offering document automation, e-discovery, analytics and other novel services like chatbots. ${ }^{81}$ These new providers place pressure on existing firms to deliver more value and greater efficiency, ${ }^{82}$ and their emergence has been accompanied by law firms focusing on their own internal productivity and profitability. This has resulted in increasing adoption, particularly in the top-tier firm sector, of modernised processes and commercialised practices ${ }^{83}$ domestic and international expansion, more intense 'talent' procurement and retention measures, performance-based pricing ${ }^{84}$ and explicit emphasis on 'innovation' in legal 'products' and processes. ${ }^{85}$ These various pressures and efforts to increase productivity have only been accelerated by the impacts of the COVID-19 pandemic. ${ }^{86}$

If the professional firm's inherent need to maintain quality and profitability ${ }^{87}$ are seen as distinct ends, and these contextual shifts are viewed as pulling away from some (implicitly ideal) traditional form of (autonomous, trusted, ethical) legal work, there remains an 'uneasy' tension between the imperatives of management and the principles of professionalism. ${ }^{88}$ The profession's expertise, it is argued, becomes less 'bespoke' and more standardised, systematised, packaged and commoditised. ${ }^{89}$ This reconfigured landscape is underpinned by a new market-oriented language of professionalism, conceiving of lawyers (and professionals) as legal 'service providers', ${ }^{90}$ owing duties to a range of 'stakeholders' ${ }^{91}$ The discursive shift to the professional as the provider and the client as the consumer aligned or aligns the legal profession with the general orientation of project management towards the delivery of a client 'value proposition'. ${ }^{2}$ With these ideas about professionalism versus managerialism, simplified in Noordegraaf's axes of coordination of work, authority, and values at stake, we examine LPM in Part IV.

Nonetheless, these discussions are not straightforward. As Noordegraaf puts it, the 'debates have moved beyond dualistic and oppositional understandings of professionalism versus managerialism and have stressed new professional/managerial combinations in organized work settings' 93 in what is now called 'hybrid' professionalism:

Services, for example, might still meet classic quality standards, including professional attention, time and humanity, but also meet quality standards like timeliness, speedy and efficiency ... Not merely offering quality when [client] cases are treated [or otherwise handled by professionals], but organizing for quality becomes a central ingredient of professional work. ${ }^{94}$

Law firms can be considered hybrid organisations, 'balancing professional and commercial goals', but while in some firms (or practices), these logics are more aligned, in others one is more dominant. ${ }^{95}$ Lander and colleagues show how law firms that emphasise the commercial/managerial logic 'outperform their peers in terms of profitability, whereas those focused on the professional/trustee logic outperform by showing low levels of professional misconduct' ${ }^{96}$ When logics align, organisations

${ }^{76}$ Henderson, "Big Law," 8. In New South Wales, the proportion of solicitors practising corporate in-house grew from 15.83 per cent $(\sim 3$ 263 lawyers) in 2006 (Law Society of New South Wales 2006, 2) to 19.7 per cent ( 6 450 lawyers) in 2018 (Urbis, 2018 National Profile of Solicitors, 44).

77 Empson, "Institutional Work Dyads," 815, citing Galanter, "Elastic Tournament."

${ }^{78}$ Henderson, "Big Law," 13.

${ }^{79}$ Carroll, "Matter Mills and London-Lite offices."

${ }^{80}$ Bleby, "New Generation of Law firms."

${ }^{81}$ Melbourne Law School, 2018 Australia: State of the Legal Market, 13.

${ }^{82}$ Rose, "Wait for ABSs Is Over."

${ }^{83}$ Commbank, Legal Market Pulse Report, 15-16.

${ }^{84}$ Woldow, "A Trend at the Tipping Point."

${ }^{85}$ Chin, State of Legal Innovation, 9-10.

${ }^{86}$ Cohen, "COVID-19 Will Turbocharge Legal Industry."

${ }^{87}$ The 'dual' objectives of law firms: Lander, "Drift or Alignment?" 123.

${ }^{88}$ Noordegraaf, "Hybrid Professionalism and Beyond," 197.

${ }^{89}$ Susskind, End of Lawyers? 37.

${ }^{90}$ Flood, "Re-Landscaping," 520.

${ }^{91}$ Noordegraaf, "Hybrid Professionalism and Beyond," 188.

${ }^{92}$ Widdop, "Legal Project Management," 34; Konstantinou, "Professionalism in Project Management."

${ }^{93}$ Noordegraaf, "Hybrid Professionalism and Beyond," 188, citations excluded.

${ }^{94}$ Noordegraaf, "Hybrid Professionalism and Beyond," 188 (emphasis in original).

${ }^{95}$ Lander, "Drift or Alignment?" 125, citing Greenwood, "Institutional Complexity," 355.

${ }^{96}$ Lander, "Drift or Alignment?" 125. 
can create "internally coherent organizational configurations' ${ }^{97}$ where they enhance each other and perform highly in both dimensions. In a study of 'hybridised' professionalism and 'institutional work', ${ }^{98}$ Empson, Cleaver and Allen document how 'non-lawyer managers' evolved alongside the rise in managerial and commercial values in the legal profession. They chart the progression from a relative dearth of these management experts in the early 1990s to a heightened role for senior management professionals (such as CFOs, COOs and financial directors) by the mid-2000s. However, as evidence of the robustness of professionalism, ${ }^{99}$ Empson and colleagues found that senior managers typically operate within the traditional ownership and control structure, thus maintaining the 'beliefs and behaviours', of the professional partnership. ${ }^{100}$

Nonetheless, Noordegraaf argues that the sweeps of managerialism have moved the professions 'beyond hybridity' to a state where 'organizing case treatment' (or the client's service) is 'part of the job' (of being a professional). ${ }^{101}$ He stresses that 'there is no necessary "coupling" and natural "blending" of logics'. 102 There may be major tension points between professionalism and managerialism, but when professionals 'feel and see contradictions' between them, they are 'able to deal with them'. ${ }^{103}$ Thus, being a professional means working out the blends of professionalism (carefulness) and managerialism (efficiency) and doing so jointly with others (other clients, managers, staff, other stakeholders). Professionals navigate these 'imperatives, objectives, interests and requirements ${ }^{\prime 104}$ and it is not always possible to distinguish managerialism from professionalism because their discourses (and practices) overlap. ${ }^{105}$ For example, professional client interest may sometimes look the same as managerial (customer-focused) empowerment. For these writers, hybridised and other forms of organisational professionalism can support cooperation and connection between professionals, colleagues and clients; professionals might not simply account for their actions (as in the case of managerialised professionalism) but take more active responsibility in trying to gain legitimacy from their 'stakeholders'. ${ }^{106}$ Values are not singular or in opposition, but intersectional, so '[q]uality and efficiency both belong to professional work' ${ }^{107}$ Examination of LPM as a new managerial practice needs to prepare for the possibility of such multiple meanings.

\section{Part III: Projectification and the Legal Profession}

\section{A-Project Management}

Since the 1990s, a form of managerialism that uses projects and project management techniques has emerged, ${ }^{108}$ termed a process of 'projectification'. ${ }^{109}$ Professional 'services' in many areas, across private and public sectors, have been transformed into projects or 'temporary modes of organising'. ${ }^{110}$ The move to 'non-permanent', 'task-focused' structures ${ }^{111}$ started in the private sector, in 'project-based' areas such as engineering and construction. After being transferred ('gradually and rather silently') ${ }^{112}$ to public organisations, projectification is now regarded as an important recent change to their administration. ${ }^{113} \mathrm{~A}$ project is defined as 'a temporary endeavour undertaken to create a unique product, service or result' and project management is defined as 'the application of knowledge, skills, tools and techniques to project activities to meet project requirements'. ${ }^{114}$ Hodgson and colleagues write that:

\footnotetext{
${ }^{97}$ Lander, "Drift or Alignment?" 124.

${ }^{98}$ Institutional work is the done by individuals and groups to change or protect certain institutional logics. It occurs through the actions of, and interactions between, for instance, in the legal context, management professionals, managing partners and the (employed or selfemployed) lawyers themselves: Empson, "Institutional Work Dyads," 809-10.

${ }^{99}$ Morris and Pinnington concluded from their study of UK law firms that legal organisations are the most the most robust organisations across the professions as far as keeping their traditional arrangements, locations of control (among the partners) and underlying professional values. They argue that any MPB (managed professional business) characteristics that have been brought into these firms have not transformed $\mathrm{P}^{2}$ interpretive schemes but have reinforced them: Pinnington, "Archetype Change," 94-96.

${ }^{100}$ Empson, "Institutional Work Dyads," 817.

101 Noordegraaf, "Hybrid Professionalism and Beyond," 202.

102 Noordegraaf, "Hybrid Professionalism and Beyond," 202.

103 Noordegraaf, "Hybrid Professionalism and Beyond," 202.

${ }^{104}$ Olakivi, "Rethinking Managerialism," 21, citations excluded.

105 Olakivi, "Rethinking Managerialism," 21.

106 Noordegraaf, "Hybrid Professionalism and Beyond," 201.

${ }^{107}$ Noordegraaf, "Hybrid Professionalism and Beyond," 201.

${ }^{108}$ Kuura, "Policies for Projectification," 118, citing Midler, "Projectification of the Firm," as introducing the concept of projectification; though noting that Packendorff, "Temporary Society," argued it dates back further.

${ }^{109}$ Midler, "Projectification of the Firm;" Lindgren, "What's New."

${ }^{110}$ Hodgson, "Introduction," 1.

${ }^{111}$ Hodgson, "Introduction," 1.

112 Hodgson, "Introduction,” 2, citing Sjöblom, “Administrative Short-Termism," 166.

${ }^{113}$ Hodgson, "Introduction,” 1, citing Sjöblom, “Administrative Short-Termism,” 165.

${ }^{114}$ Project Management Institute, PMBoK Guide, 4-5, 10.
} 
it is difficult to dispute the growing prevalence of projects in contemporary societies, with increasing numbers of employees being redefined as project leads or project managers, and a creeping adoption of the language and forms of projects and project management outside their traditional heartlands of engineering and technology - into the media, healthcare, research, and performing arts. ${ }^{115}$

As we show below, projects have also come to law.

The organisational literature singles out two forms or levels of projectification. ${ }^{116}$ The first, more specific level '[describes] organisational restructuring within a firm to place projects as key units by which production could be organised'. ${ }^{117}$ Aubry, Hobbs and Thuillier define 'organisational project management' as 'a new sphere of management where dynamic structures in the firm are articulated as a means to implement corporate objectives through projects in order to maximise value'. ${ }^{118}$ Hodgson and colleagues note that some writers characterise the use of 'projectification' in this context as typically favourable; it may 'enable other positive developments within organisations such as increasing flexibility, innovation, customer focus, and efficiency'. ${ }^{119}$ Like managerialism more broadly, projectification has been accelerated by the widespread use of information and communications technology to simplify the management of projects. ${ }^{120}$ Thus, 'projects are thought to provide flexibility, accelerate decision-making processes, increase problem-solving capabilities and innovativeness, and deliver strategic goals' ${ }^{121}$ Essentially, projects are adaptive technologies. Projectification is one way in which organisations can respond to their conditions of 'contingency, unpredictability, and rapid change', ${ }^{122}$ where projects are seen as 'a superior way of reacting to unanticipated and irregular situations'. ${ }^{123}$

The second, expansive view of projectification ${ }^{124}$ is associated with a more critical analytical approach, by which the currency of the project, comprising 'principles, rules, techniques and procedures', ${ }^{125}$ permeates not just organisations, but societies. Hodgson and colleagues observe: 'Over time, the narrow and broad definitions of projectification come to reinforce one another, as practical organisational arrangements meet a greater degree of acceptance in a broader and broader array of sociocultural settings'. ${ }^{26}$

Meanwhile, project management began to formalise into a discipline in the $1950 \mathrm{~s}$ and $1960 \mathrm{~s} .{ }^{127}$ This period saw the introduction of key tools such as the 'critical path' method in 1957, the 'program evaluation and review technique' in 1958, the work breakdown structure in 1962 and the time-cost-quality 'triple constraint ${ }^{\prime} 28$ in 1969. Project management associations formed, such as the American Association of Cost Engineers in 1956, the International Project Management Association in 1965 and the Project Management Institute (PMI) in 1969. Yet, it was not until the 1980s 'that a real panel of specialists was created: with an ethical code, clearly identified knowledge, and certification' ${ }^{129}$ Contemporaneously, the associations formalised their 'body of knowledge' through the development of unifying standards. The project management profession has continued to evolve, most notably by adopting the idea that its approaches need to be capable of successfully delivering projects within an increasingly complex environment. ${ }^{130}$

\footnotetext{
${ }^{115}$ Hodgson, "Introduction," 1, citing Lindgren, "What's New."

116 Hodgson, "Introduction," 1-3.

${ }^{117}$ Hodgson, "Introduction," 2.

118 Aubry, "New Framework," 32.

${ }^{119}$ Hodgson, "Introduction," 2, citing Frame, New Project Management, and Gemünden, "Projectification of Society."

${ }^{120}$ Shaw, "Standardisation and its Consequences," 232, citing Cicmil, "Understanding Project Management Practice;" Morris, "Introduction: Towards the Third Wave."

${ }^{121}$ Shaw, "Standardisation and its Consequences," 232, citing Sjöblom, "Projectified Politics."

122 Shaw, "Standardisation and its Consequences," 231, citing Mautner, Language and Market Society.

${ }^{123}$ Sjöblom, "Projectified Politics," 3, quoted by Shaw, "Standardisation and its Consequences," 232.

${ }^{124}$ Lindgren, "What's New," 841-44.

${ }^{125}$ Shaw, "Standardisation and its Consequences," 231; citing Hodgson, "The Other Side of Projects."

${ }^{126}$ Hodgson, "Introduction," 2.

${ }^{127}$ Padalkar, "Six Decades," 1305.

128 The triple constraint identifies a relationship between the time to deliver a project, the cost to deliver the project and the required level of quality for the project. Under the model, increasing or decreasing any one of these factors ('constraints') will have an effect upon the others. ${ }^{129}$ Clegg, "Political Hybrids," 527.

${ }^{130}$ Hodgson, "Disciplining the Professional;" Paton, "Price of Corporate Professionalism;" Paton, "Project Managers on the Edge," 27; Dombkins, Complex Project Management, 291-93.
} 
Worldwide, there are many professional project management associations. Among other things, they certify or accredit project managers. ${ }^{131}$ Noting the popularity of such associations, Morris and colleagues characterise project management as a 'semi' or 'emerging' profession, legitimated, in their view, by formal bodies of knowledge rather than a contribution to the public good or ethical code. ${ }^{132}$ Muzio and colleagues have also identified project management's quest for professional legitimisation, noting that this tends to occur via a commercial focus on 'delivering value', with the benefits of membership of professional associations couched in fiscal terms rather than professional community and public interest. ${ }^{133}$ Part IV analyses LPM for its significance for professionalism according to Noordegraaf's three core features of professionalism, with this backdrop presenting a skew towards sharply managerial practices and beliefs.

\section{B-Legal Project Management}

To make itself compatible with legal expertise, LPM reframes all legal matters as projects. Its breadth as a 'suitcase' term ${ }^{134}$ means that its practitioners subsume numerous management approaches into their expertise. ${ }^{135}$ In moving to be the principal answer to law firms' complicated environments, some LPM practitioners say that LPM is any management approach that serves lawyers' objectives: 'If a proven technique can help lawyers accomplish their goals, we say it is part of LPM' ${ }^{136}$ More often though, the LPM literature asserts the need to adapt existing project management approaches to meet the unique requirements of the legal profession, ${ }^{137}$ with other disciplines such as organisational design and process improvement often regarded as separate to LPM. ${ }^{138}$ In this section, we draw on LPM literature, much of it practitioner-focused, and available statistics about LPM uptake. We supplement these sources with approximate numbers of self-identifying LPM practitioners, contrasted with other groups using similar skills.

Project management is widely used across many organisations. A review of project management literature sourced nearly 95,000 unique abstracts, demonstrating the area's breadth of research. ${ }^{139}$ However, the expansion of project management to legal matters came relatively late. In the early 2010s, US firms began formalising their training of LPM practitioners and touting the advantages of LPM. For example, Dechert LLP and Nixon Peabody established LPM programs in $2010 .{ }^{140}$ In the same year, the industry magazine, The American Lawyer, published its first article on LPM ${ }^{141}$ and a law review article advocated for the adoption of LPM (and its consistency with professional obligations). ${ }^{142}$ In 2017, a US survey found that approximately half of 103 respondents' firms were 'much more focused on legal project management principles and technology' than in $2012 .{ }^{143}$

131 'There is also a large body of best practice journals bearing evidence of project management as an evolving academic field. In addition, the ISO (International Organization for Standardization) has developed a specific standard for project management (ISO21500, effectuated in 2012), heavily influenced by the International Project Management Association': Hodgson, "Introduction," 3.

${ }^{132}$ Morris, "Exploring the Role," 711.

${ }^{133}$ Muzio, "Towards Corporate Professionalization," 454-55. This may not be entirely fair in the case of Project Management, where the professionals' duties are, at least formally, as onerous as those of the established professions. For example, the Australian Institute of Project Management's code of conduct requires integrity (i.e., honesty and avoiding conflicts of interest), competence, lawfulness and upholding the profession's reputation. It also includes leadership and responsibility, an expansive commitment including social and environmental interests. The UK's Association of Project Management advances similar, individual responsibilities in its code of conduct, as well as wider responsibilities to the overall profession of project management and the professional development, including the ethical development of staff and colleagues. The US-based PMI's code advances four professional values, responsibility, respect, fairness and honesty, and has also developed an ethical decision-making framework. Having said that, the industry and academic discussion of project management is almost entirely market-focused.

${ }^{134}$ A term first coined by Minsky, The Emotion Machine, 109.

135 'Projectification' is the means 'through which project managers have legitimized their role, and greatly expanded the boundaries of their own jurisdiction to colonize new domains': Muzio, "Towards Corporate Professionalization," 447, citing Boltanski, The New Spirit of Capitalism.

${ }^{136}$ Hassett, Keys to Legal Project Management, 14.

${ }^{137}$ Maister, "The Trouble with Lawyers;" Lambreth, Transforming Legal Services, 3; Palomaki, "Legal Project Management from the Inside;" Hassett, Keys to Legal Project Management, 14-15; Woldow, Legal Project Management in One Hour, 1; Lambert, "Is It 'Legal' Project Management."

${ }^{138}$ However, LPM's jurisdictional lines are contested. Some say LPM is a broader term that encompasses organisational design (Hassett, Keys to Legal Project Management, 15-17) and others say that organisational design principles are separate to LPM (Woldow, Legal Project Management in One Hour, 9-10). Further, others have labelled the application of organisational design principles to legal practices as 'legal operations', which is concerned to optimise legal service delivery within legal organisations. These LPM boundaries and hierarchies are yet to be settled. To be legitimate, professional knowledge must be perceived as being objective and not simply up to individual practitioners (Abel, "The Legal Profession," 9) and therefore, these contests about LPM are likely ongoing.

${ }^{139}$ Pollack, "Emergent Trends."

${ }^{140}$ Passarella, "Dechert Puts Its Attorneys;" Cohen, "Six Big Law Firms."

${ }^{141}$ Hassett, "Teach Lawyers."

${ }^{142}$ Plitz, "Manage What Matters."

${ }^{143}$ Exterro, Law Firm Benchmarking Report, 28 (51 per cent). 
LPM soon made its way to Australia. For example, in 2012, King \& Wood Mallesons announced its internal LPM training program as the first in the Australian market, ${ }^{144}$ and the use of LPM techniques by 'innovative lawyers' was noted in the Law Council of Australia's Australasian Law Management Journal. ${ }^{145}$ By 2014, the first LPM textbook was released in Australia. ${ }^{146}$

As mentioned, in-house counsel is a growing segment of the legal profession and a critical group driving managerialism, including LPM. ${ }^{147}$ There is some empirical evidence of LPM's prevalence among in-house counsel (both within their own organisations and as clients of external firms); a global 2017 survey of general counsel found that 62 per cent of respondents were 'taking steps to improve the project management skills of their teams'. ${ }^{148}$

Industry research is raising awareness among LPM practitioners and lawyers of a 'value for clients' metric. A 2018 survey by Altman Weil asked 398 US law firms to rate how 'serious' they were about 'changing their legal service delivery model to provide greater value to clients (as opposed to simply cutting costs)' ${ }^{149}$ Notwithstanding discussions of 'client value', over half of the respondent firms indicated a low commitment. ${ }^{150}$ It was also reported that over 90 per cent of respondent Chief Legal Officers agreed their external counsel had a low commitment. ${ }^{151}$ LPM practitioners note the discrepancy between firms' selfperceptions and the perceptions of clients and the significant business opportunity that addressing this discrepancy could produce. ${ }^{152}$

These industry moves to introduce LPM have garnered institutional support. The Corporate Legal Operations Consortium (CLOC), a global association of in-house legal departments, has developed an LPM working group and framework. ${ }^{153}$ Both CLOC and the Association of Corporate Counsel have developed separate legal operations 'maturity' models that include project management. ${ }^{154}$ LPM is a subset of project management associations, including the Australian Institute of Project Management (AIPM), the UK Association for Project Management and the PMI. LPM practitioners can also draw upon boutique LPM training organisations, such as LawVision, LegalBizDev and the International Institute of Legal Project Management. ${ }^{155}$ In addition to hiring and/or training their lawyers as LPM practitioners, various large private practice firms and alternative legal service providers have commenced offering consultancy services in legal operations, some of which include LPM capability development. ${ }^{156}$

Meanwhile, the American Bar Association recognises LPM as an efficiency tool. ${ }^{157}$ In the UK, the 2013 Legal Education and Training Review, an initiative of the Solicitors Regulation Authority (SRA), the Bar Standards Board and the Chartered Institute of Legal Executives (CILEx), identified management (including project management and broader organisational management) as a skills shortage area among UK solicitors. ${ }^{158}$ In 2015, the SRA published its 'Statement of solicitor competence', which holds that solicitors should be able to 'initiate, plan, prioritise and manage work activities and projects to ensure that they are completed efficiently, on time and to an appropriate standard' ${ }^{159}$ In Australia, reports by the NSW and Victorian Law Societies identify LPM as a required future competency of lawyers ${ }^{160}$ and offer training in LPM through continuing professional development programs. As of 2019, the University of New South Wales has offered LPM subjects and the College of Law has offered LPM short courses. In 2018, AIPM adapted its national project management certification framework to certify lawyers as project managers. ${ }^{161}$

\footnotetext{
${ }^{144}$ Lowe, "King \& Wood Mallesons."

${ }^{145}$ Harris, "Future Firm," 26.

${ }^{146}$ Linton, Legal Project Management.

${ }^{147}$ Boake, Project Management for Lawyers, 4.

148 Ashurst Advance, "Riding the winds of change."

${ }^{149}$ Clay, Law Firms in Transition, 13-14.

${ }^{150}$ Clay, Law Firms in Transition,"13, finding that 57.3 per cent of surveyed law firms rated their commitment as 'low'.

${ }^{151}$ Clay, Law firms in Transition, 14, reporting that, when asked the same question in 2017, only 9.4 per cent of surveyed Chief Legal Officers (CLOs) rated their external law firms' commitment at 6 (out of 10) or higher, and no CLO rated their external law firms at 9 or 10.

${ }^{152}$ Hassett, Keys to Legal Project Management, 2-3.

$153 \mathrm{https} / / /$ cloc.org/legal-project-management/

154 Association of Corporate Counsel, "Maturity Model."

${ }^{155}$ Such as Levy, Legal Project Management; Hassett, Legal Project Management, Pricing, and Alternative Fee Arrangements; and Linton, Legal Project Management.

${ }^{156}$ Including (but not limited to) the 'Big 4' accounting firms (such as PwC's NewLaw), ALSPs (such as Axiom and Elevate Services) and global law firms (such as Ashurst and Seyfarth Shaw).

${ }_{157}$ American Bar Association, Report on the Future of Legal Services, 29.

${ }^{158}$ Legal Education and Training Review, Setting Standards, 112.

${ }^{159}$ Solicitors Regulation Authority, "Statement of Solicitor Competence."

${ }^{160}$ Law Society of New South Wales, Future of Law and Innovation in the Profession, 48; Law Institute of Victoria, Disruption, Innovation and Change, 3 .

${ }^{161}$ Australian Institute of Project Management, "Gilbert + Tobin leads the way."
} 
Nonetheless, available empirical evidence suggests that LPM adoption remains slow. According to one survey, 29 per cent of 126 participating US firms had structured project practices in place, and only 15 per cent rated themselves with a 'high' project management maturity level. ${ }^{162}$ Recent market surveys have revealed mixed results. In 2009, the International Legal Technology Association reported a shift from practices exploring LPM to 'respondents ... indicating that their LPM program is in progress, formed or mature'. ${ }^{163}$ Altman Weil reported that one-third of US firms surveyed had engaged in 'ongoing project management training and support' to increase the efficiency of service delivery. However, under 20 per cent were systematically reengineering their work processes. ${ }^{164}$ Only one-quarter of surveyed Chief Legal Officers reportedly used LPM to increase the efficiency of service delivery. ${ }^{165}$

Widdop, an LPM practitioner, observes that few legal practices have successfully embedded LPM as an integral part of their service offering. ${ }^{166}$ Nonetheless, based upon US data from 2013, Lambreth, another practitioner, argues that LPM is becoming more entrenched within legal services' delivery. She claims that over half of 'AmLaw 100' firms have professionals functioning as legal project managers or leading LPM initiatives. Further, she claims that over half 'of legal organizations' have 'a budgeting tool for developing budgets or estimating the cost of legal matters prior to initiating the project' and that similar numbers 'are requiring more detailed engagement letters or scope of work agreements at the start of new legal matters'; the source of these statistics is not provided. ${ }^{167}$

Regarding the Australian legal market, a 2017 report asserted that 'a large number of firms are increasing the amount they invest in legal project management training and tools in response to increasing levels of client demand for more accurate price estimation and resource planning'. ${ }^{168}$ Again, however, no substantiating data was provided. Another 2017 Australian survey showed that only 19 per cent of responding law firms used project management software. ${ }^{169}$

The primary protagonists embedding the use of LPM within firms and organisations are LPM practitioners, including practising lawyers who are trained or certified in project management. However, the number of LPM practitioners remains difficult to determine. ${ }^{170}$ To gain a clearer sense of the number of practitioners, we estimated the number using the professional social networking site 'LinkedIn', tallying the number of those self-identifying globally as LPM practitioners, as well as within specific jurisdictions (Australia, the United Kingdom and the United States ${ }^{171}$ ). As explained below, we used Boolean search queries to search for specific words associated with LPM practitioners and related roles appearing anywhere in an individual's LinkedIn profile - whether as a current or former job title or description or as part of their listed 'skills'. Noting that not all LPM practitioners may have LinkedIn profiles (the sampling frame may not include the total population), as a calibration activity, we identified the most recent data of the number of legal practitioners in Australia, the UK and the US as appears on LinkedIn, and compared this against the number of legal practitioners as published by each respective jurisdiction's national legal professional body (see Table 1). ${ }^{172}$

Table 1: The Population of Legal Practitioners on LinkedIn

\begin{tabular}{|l|r|r|}
\hline \multicolumn{1}{|c|}{ Jurisdiction } & $\begin{array}{c}\text { Identified LinkedIn Profiles } \\
\text { (approximate as of June 2020) }\end{array}$ & \multicolumn{1}{c|}{ Official Number of Legal Practitioners } \\
\hline Australia & 76,000 & $76,303($ as at October 2018) \\
\hline UK & 212,000 & $201,873($ as at May 2020) \\
\hline USA & $1,380,000$ & $1,338,678(\text { as at May } 2018)^{175}$ \\
\hline
\end{tabular}

${ }^{162}$ Ali, "Legal Aid," 13.

${ }^{163}$ Heimerl, Mini White Paper, 6.

164 Clay, Law Firms in Transition, 53.

165 Clay, Law Firms in Transition, 53.

166 Widdop, "Legal Project Management," 33-34.

${ }^{167}$ Lambreth, Clients are Demanding, 3.

${ }^{168}$ Melbourne Law School, 2018 Australia, 8.

169 Ali, "Legal Aid," 13.

${ }^{170}$ Friston, On Costs, ch 41.

${ }^{171}$ Boolean search strings were used and the industry filters of 'law practice' and 'legal services' were selected to limit search results to the legal sector. Noting that the search queries used English terms, English-speaking jurisdictions were selected for specific analysis.

${ }^{172}$ To do so, the Boolean search query "lawyer" OR "associate" OR "partner" OR "attorney" OR "counsel” OR "solicitor" was used, applying the industry filters of 'law practice' and 'legal services' to filter LinkedIn profiles.

${ }^{173}$ Urbis, 2018 National Profile of Solicitors, 2.

${ }^{174}$ Solicitors Regulation Authority, "Population of solicitors in England and Wales."

175 Weiss, "Lawyer population $15 \%$ higher." 
This calibration exercise indicated that, at least regarding the legal profession across Australia, the UK and the US, LinkedIn data approximates the total population of legal practitioners.

Similar Boolean search methods were subsequently used to identify those individuals self-describing as engaging in LPM or related roles and working in law practices or legal services. We included 'matter management' within the words used to describe 'LPM' and included 'case management', 'pricing practitioner' and 'process improvement' as related roles. While 'matter management' generally refers to project managing any type of legal matter, 'case management' generally refers to project managing litigation matters only (the series of steps by which a dispute proceeds to a trial before a court). Pricing specialists have similar competencies to LPM practitioners in relation to scoping and costing, whereas process improvement practitioners have common competency areas to LPM regarding task management and feedback. Table 2 shows the approximate numbers of unique profiles of LPM practitioners or similar roles identified in the 'law practice' and 'legal services' industries, according to LinkedIn as of June 2020. The population of case management, matter management, pricing and process improvement practitioners, whose core competencies overlap to various extents with LPM practitioners, is much wider than the population of self-identifying LPM practitioners.

We then collected information about how many of these LinkedIn profiles also identified as lawyers. As shown in Table 2 , 80 per cent of self-identifying LPM practitioners also identify as legal practitioners, as do 52 per cent of self-identifying case managers. However, only 30 per cent of self-identifying 'process improvement' practitioners also identify as legal practitioners. This dominance of LPM practitioners who are also legally trained, or are lawyers jointly practising LPM, fits a picture of LPM growing as an expertise that is especially 'designed for attorneys rather than project managers'. ${ }^{176}$

Table 2. The Number of LPM Practitioners in Law Practice and Legal Services on LinkedIn, 2020

\begin{tabular}{|l|r|r|r|r|}
\hline & \multicolumn{1}{|c|}{ LPM $^{\mathbf{1 7 7}}$} & $\begin{array}{c}\text { Case } \\
\text { Management }\end{array}$ & $\begin{array}{c}\text { Pricing } \\
\text { Practitioner }^{\mathbf{1 7 9}}\end{array}$ & $\begin{array}{c}\text { Process } \\
\text { Improvement }^{\mathbf{1 8 0}}\end{array}$ \\
\hline Australia & 416 & 1700 & 1000 & 2500 \\
\hline UK & 775 & 8600 & 2300 & 5500 \\
\hline USA & 2400 & 44000 & 11000 & 27000 \\
\hline All locations & 5000 & 61000 & 29000 & 46000 \\
\hline Also lawyers (all locations) & 4028 & 32000 & $38 \%$ & 14000 \\
\hline $\begin{array}{l}\text { Per cent also lawyers (all } \\
\text { locations) }\end{array}$ & $80 \%$ & $52 \%$ & $30 \%$ \\
\hline
\end{tabular}

\section{Part IV: LPM as Projectification}

As signalled, to analyse LPM, we use Noordegraaf's three core features of professionalism that are set up for comparison with managerialism. ${ }^{182}$ These axes cover, in a simple way, multi-level meanings (individual, professional and social), while being grounded within the organisation where managerial practices are enacted. ${ }^{183}$ They also provide a way of comparing features, specifically, how work is coordinated, how professional authority is established, and what values are at stake. As Noordegraaf explains:

Professionalism is generally seen as something that has much to do with coordination of skills of autonomous workers, authority on the basis of trust, and quality as a core professional value. Managerialism is seen as something that has much to do with coordination through various forms of control, authority on the basis of (tangible) results, and efficiency as a core value. ${ }^{184}$

\footnotetext{
${ }^{176}$ Levy, Legal Project Management, 21.

177 Search query ("legal project management" OR "LPM" OR "legal project manager").

${ }^{178}$ Search query ("legal” AND ("case management" OR "case manager").

${ }^{179}$ Search query "pricing."

${ }^{180}$ Search query ("process" AND "improvement").

${ }^{181}$ Using the additional Boolean search terms AND ("attorney" OR "solicitor").

${ }^{182}$ Noordegraaf, "Hybrid Professionalism and Beyond."

${ }^{183}$ Noordegraaf, "Hybrid Professionalism and Beyond," 189.

${ }^{184}$ Noordegraaf, "Hybrid Professionalism and Beyond," 189.
} 
Table 3 outlines these principles and their dimensions, along with our analysis. Within each principle that orders our analysis, we explore the related contrarieties found within the discussion of projectification. We assess whether arranging and talking about professional work as projects offers professionals more innovative, collaborative, open and flexible ways of working. These could be seen in some respects as a reworked professionalism for contemporary times, not just Noordegraaf's 'organised professionalism' but also a break from organisational ideals. Or else, projectification could be diffusing more intensive (and intense) managerialism, through standardised and centralised control and monitoring.

Table 3. A Comparison of Core Features of Professionalism in a Traditional Professional Partnership, Managed Professional Business, and Managed Professional Business Applying LPM

\begin{tabular}{|c|c|c|c|c|}
\hline Principles & Dimensions & $\begin{array}{l}\text { Traditional Professional } \\
\text { Partnership ( } \mathbf{P}^{2} \\
\text { model })^{185}\end{array}$ & $\begin{array}{l}\text { Managed Professional } \\
\text { Business }\end{array}$ & $\begin{array}{l}\text { Managed Professional } \\
\text { Business Applying LPM }\end{array}$ \\
\hline \multirow[t]{2}{*}{$\begin{array}{l}\text { How work is } \\
\text { coordinated }\end{array}$} & Process & $\begin{array}{l}\text { Informal and implicit product } \\
\text { of socialisation and expert } \\
\text { knowledge }\end{array}$ & $\begin{array}{l}\text { Managerial processes } \\
\text { documented, target-setting } \\
\text { and performance } \\
\text { management systems }\end{array}$ & $\begin{array}{l}\text { Legal and managerial } \\
\text { processes intensively } \\
\text { documented }\end{array}$ \\
\hline & Standardisation & $\begin{array}{l}\text { Incompatible with } \\
\text { professional autonomy and } \\
\text { quality, standardises 'inputs } \\
\text { rather than processes' } 186\end{array}$ & $\begin{array}{l}\text { A control mechanism, } \\
\text { standardised processing for } \\
\text { quality }\end{array}$ & $\begin{array}{l}\text { Cost/time reduction, } \\
\text { efficiency gains, high } \\
\text { standardisation }\end{array}$ \\
\hline \multirow[t]{2}{*}{$\begin{array}{l}\text { How } \\
\text { authority is } \\
\text { established }\end{array}$} & Relationships & $\begin{array}{l}\text { Consultative, distribution of } \\
\text { authority across partners, } \\
\text { decentralised decision- } \\
\text { making }\end{array}$ & $\begin{array}{l}\text { Directive decision-making, } \\
\text { formalised management }\end{array}$ & $\begin{array}{l}\text { Project-based teams, control } \\
\text { via extensive planning and } \\
\text { reporting, sharing } \\
\text { professional knowledge }\end{array}$ \\
\hline & Competencies & Legal skills only & $\begin{array}{l}\text { Legal and } \\
\text { business/managerial skills }\end{array}$ & $\begin{array}{l}\text { Legal, business and legal } \\
\text { project management skills }\end{array}$ \\
\hline \multirow[t]{2}{*}{$\begin{array}{l}\text { What values } \\
\text { are at stake }\end{array}$} & Communication & $\begin{array}{l}\text { Information asymmetry, } \\
\text { opaque, intermittent rather } \\
\text { than continuous }\end{array}$ & $\begin{array}{l}\text { Siloed, only management has } \\
\text { access to core data }\end{array}$ & $\begin{array}{l}\text { Transparency, data-informed } \\
\text { decision-making, increased } \\
\text { surveillance }\end{array}$ \\
\hline & Values & $\begin{array}{l}\text { Quality and efficiency, } \\
\text { bespoke service, trusting and } \\
\text { ongoing relationships }\end{array}$ & $\begin{array}{l}\text { Responsibility; connections; } \\
\text { and stakeholders; trust } \\
\text { through results, not } \\
\text { relationships }\end{array}$ & $\begin{array}{l}\text { Efficiency, disaggregation } \\
\text { and trust based on } \\
\text { documented planning, } \\
\text { transparency and costs } \\
\text { control }\end{array}$ \\
\hline
\end{tabular}

\section{A-Coordination}

A central tenet of LPM is its espousal of explicit, documented processes and standardisation. We discuss these two dimensions in relation to Noordegraaf's description of principles concerning how work is coordinated. ${ }^{187}$ He contrasts professionalism's coordination of the (shared) skills, norms and commitment of otherwise 'autonomous workers' with managerialism's more explicitly 'controlling' elements, which may be market-based. ${ }^{188}$

Professionals do not lack a process by which to undertake their work. Through their education and socialisation, 'they acquire knowledge, skills and experiences ... develop a professional "habitus" and they know what to do when they perform their work'. ${ }^{189}$ This may be a simple series of steps: meeting the client, opening a file, taking instructions, drafting advice and so on. LPM, though, seeks to 'projectify' through disaggregation into component phases, for example, matter initiation, matter

185 Greenwood, "“P2-form' Strategic Management."

186 Pinnington, "Archetype Change," 86.

${ }^{187}$ Noordegraaf, "Hybrid Professionalism and Beyond," 188-89.

188 Noordegraaf, "Hybrid Professionalism and Beyond," 189, 191.

189 Noordegraaf, "Hybrid Professionalism and Beyond," 191 (emphasis added), citing Witman, "Doctor in the Lead." See also Lambreth, Implementing Legal Project Management, 1: 'It is not about dramatically changing the way a matter is handled ... It is fundamentally about a more proactive, disciplined approach to managing existing work to enhance the likelihood of meeting client and firm expectations'. 
planning, matter execution and reporting and matter closing. ${ }^{190}$ It also seeks to intensively document process. Its stated aims are to bring interrelated tasks together to best serve the client, "to bring order and control to the big picture-to an end result as envisioned and desired by the client, not as perceived by those doing legal work' ${ }^{191}$ It promises a 'systematic and disciplined approach'. ${ }^{192}$

In LPM, the first phase, 'strategic planning', refers to understanding the broader organisational goals of both the client and the legal practice and manifesting these into a set of project objectives. This is termed 'defining what success looks like' ${ }^{193}$ It incorporates detailed 'planning': defining each project's schedule, scope and budget constraints (using tools such as the 'triple constraint' adapted for legal services). ${ }^{194}$ It requires an understanding of the dependencies or logical relationships among project tasks; developing a work breakdown structure, which assigns a sequence, timeframe and resources to tasks; ${ }^{195}$ and using this to develop a cost estimate. ${ }^{196}$ These relationships are generally described according to when each task starts or finishes, that is, both tasks must start at the same time, one task must start or finish before the other, or both tasks must finish at the same time. ${ }^{197}$

'Tracking' and 'reporting' include monitoring tasks (and their 'dependencies') against their scheduled start and delivery dates and reporting on this progress to relevant stakeholders; for instance, itemising each planned task with the status of either 'not started', 'in progress', 'on pause' or 'completed', and noting whether each item's status is in accordance with the schedule. Some LPM practitioners use tools such as Gantt charts, deriving originally from large construction projects, for this purpose, giving a sense of LPM's mechanistic origins, focused on scoping, scheduling and costing matters. ${ }^{198}$ The use of technology, especially for budgeting, is prominent. ${ }^{199}$

These process-driven imperatives, as with other managerial techniques, at first glance would seem to be anathema to the lawyer's 'traditional' professionalism, already drastically changed-namely, the autonomy, expertise and the independence required for professional judgement. LPM's focus on common work procedures undermines individualistic approaches, and the ultimate goal is control and predictability. The key beneficiary is the client, who ideally has increased clarity about the status of their matter, ${ }^{200}$ access to accurate tracking of progress and a reduction in 'scope creep', ${ }^{201}$ where the work needing to be done, and the cost of that work, gradually increases. As has been noted in relation to time-based billing, which has a similar, dual function, ${ }^{202}$ the tracking and reporting elements also provide a tool for monitoring and controlling lawyers' progress in their work. ${ }^{203} \mathrm{~A}$ focus on scope and time also invokes explicit trade-offs, where 'quality' may be traded off for increasing speed of delivery, ${ }^{204}$ as we discuss below in relation to the implications for professional values.

However, there are ways in which LPM's character and significance are hard to pin down. For instance, LPM's mechanistic nature may also improve the lawyer-client relationship, specifically, by supporting better 'expectation management', which actually involves very human feelings and socioemotional skills. ${ }^{205}$ Typically, clients expect much of their lawyers, while lawyers are poor at managing these expectations. ${ }^{206}$ LPM may encourage ongoing, rather than intermittent, partial or infrequent communications, which better support several of the lawyers' primary 'professional' duties of ongoing disclosure, reasonable costs, avoiding conflicts, identifying errors and other matters affecting the client's capacity to properly instruct the lawyer.

${ }^{190}$ Linton, Legal Project Management. This broadly reflects the project lifecycle stages identified in the Project Management Institute's widely-recognised project management standards: Project Management Institute, PMBoK Guide, 25.

${ }^{191}$ Woldow, Legal Project Management in One Hour, 8.

${ }^{192}$ Hassett, Keys to Legal Project Management, 3.

${ }^{193}$ Project Management Institute, PMBoK Guide, 34.

${ }^{194}$ Linton, "Maximising the Benefits."

${ }^{195}$ Norman, Work Breakdown Structures, 6.

196 Preston, "Where Rubber Meets the Road."

${ }^{197}$ Project Management Institute, PMBoK Guide, 190.

${ }^{198}$ Linton, Legal Project Management, 5-6; Hassett, Keys to Legal Project Management, 3-5 (on using Gantt charts, noting they dismiss this as 'waterfall' c.f. 'agile' LPM).

199 Preston, "Where Rubber Meets the Road."

200 Boake, Project Management for Lawyers, vii.

${ }^{201}$ Lambreth, Transforming Legal Services, 4-5.

${ }^{202}$ Campbell, "Salaried Lawyers," 109.

${ }^{203}$ Preston, "Where Rubber Meets the Road."

${ }^{204}$ For instance, the triple constraint model of time-cost-quality, referred to above.

${ }^{205}$ Kiser, Soft Skills for the Effective Lawyer, 87.

${ }^{206}$ See, for instance, Office of the Legal Services Commissioner, 2017-2018 Annual Report, 27, which identifies 'communication' as a leading cause of complaints against lawyers. 
Hassett, a consultant, states that LPM supports alternative billing, stressing that its budgeting functions for the firm. ${ }^{207}$ Ideally, consistent use of LPM improves the accuracy of estimating future work. ${ }^{208}$

LPM's focus on transparency may have other, multiple meanings and effects, such as enhancing capacity for effective teamwork. ${ }^{209}$ High levels of expertise and a tradition of autonomous working habits may not predispose senior lawyers to effective teamwork. ${ }^{210}$ These predispositions are reinforced by the non-LPM, 'managed' law firm, particularly with a siloed and internally competitive structure. Lawyers may be disinclined towards internal transparency regarding their clients, ${ }^{211}$ individual performance, ${ }^{212}$ systems or generalised knowledge. ${ }^{213}$ A project approach is said to encourage teamwork, supporting and legitimating groups of different people to reach open-ended objectives. ${ }^{214}$ Greater transparency vis-à-vis clients may also correspond to greater transparency for junior lawyers, in terms of where their 'piece' of a matter fits. This might also contribute to reducing myopia around the bigger picture of the matter, which is suggested to hinder awareness of ethical issues and thus diminish professional responsibility. ${ }^{215}$ But delegation, an aspect of managed teams, is also about control, illustrating the duality of projectification: flexibility and order. ${ }^{216}$

LPM's emphasis on streamlining processes necessarily entails standardisation, including, where possible, automating parts of a process. Examples might include using document automation technology to develop a first draft document from a template, using an expert system to help automatically identify relevant legal information and/or triage (and even respond to) legal requests and automation of routine administration. LPM might also drive larger organisational changes in the form of deployment of firm-wide software for practice management, case or matter management, or work collaboration platforms.

Lawyers may be sceptical of seemingly standardised approaches. ${ }^{217}$ In relation to project management more generally, an '[o]veremphasis on didactic methodology suggesting the rote application of best practices diminishes the role of judgement that managers need in applying knowledge in different contexts'. ${ }^{218}$ Unlike 'project management' per se, legal cases tend not to be standardised. Litigious matters are unpredictable: 'steps in the project may be significantly affected by an opponent's actions, such as in litigation'. ${ }^{219}$ The corollary is that many elements of legal matters can be standardised, and this promotes consistency and efficiency.

\section{B-Authority}

Lawyers' authority has been historically or notionally based on trust, legitimated by the lawyer's 'professional' expertise and ethical commitment to the core principles of honesty, fairness, collegiality and competence. Moreover, social trustee status is primarily enacted through an individual practitioner's relationship with their client or patient, and within a wider professional community. The client trusts the individual lawyer's skill and ethicality, or at least is assured by the reputation of the profession or perhaps their firm. By contrast, in advancing adherence to process and standardisation, LPM intends to better ensure for the 'customer' certain, desirable, efficient and explicit 'results'. It can be seen as furthering the managerial shift to professional authority as based on tangible outcomes. ${ }^{220}$ As mentioned, LPM is designed to enable the client to better see the 'progress' of a matter and understand costing. Cases are broken down into smaller components, each with specific goals, costs and points at which to report back. This is how 'managed professionals' achieve and maintain authority—by proving that their 'services',

\footnotetext{
${ }^{207}$ Hassett, Legal Project Management, Pricing, and Alternative Fee Arrangements, 9; Woldow, “A Trend at the Tipping Point.” Mullan also argues that the increasing prevalence of fixed fees is a driver of LPM uptake: "Passing Fad or Here to Stay?" 214. For a full range of fee arrangement options, refer to Law Firm Pricing, "Continuum of Fee Arrangements."

${ }^{208}$ Hassett, Legal Project Management, Pricing, and Alternative Fee Arrangements; Lambreth, RFPs/Surveys, 2.

${ }^{209}$ Linton, Legal Project Management, 5-6.

${ }^{210}$ Giddings, "Preparing Future Generations;” Bell, “Artificial Intelligence and Lawyer Wellbeing,” 262.

${ }^{211}$ Salomon, "Lawyer Personality," 50-51; Furlong, "Pivot generation," 436.

${ }^{212}$ Campbell, "Salaried Lawyers," 103-5.

${ }^{213}$ Susskind, End of Lawyers? 158-60.

${ }^{214}$ Fred, "Local Government Projectification," 365.

${ }^{215}$ Parker, "Ethical Infrastructure."

${ }^{216}$ Fred, "Local Government Projectification," 364-66.

${ }^{217}$ Bell, "Artificial Intelligence and Lawyer Wellbeing," 254-58; Susskind, End of Lawyers? 37: 'the instinct has been the opposite: to double down on 'bespoke work' and market that as a specialisation'. See also Lambert, "Is It 'Legal' Project Management," quoting Timothy Corcoran, a 'Legal Technology \& Marketing Executive': 'lawyers often don't readily acknowledge that there isn't infinite variability and "art" in their legal work, and much of what they do in matter A is applicable in matter B, and so on. They tend to equate repeatability with commodity, and few lawyers believe s/he practices commodity law'.

${ }^{218}$ Morris, "Exploring the Role," 719.

${ }^{219}$ Legg, "New Skills," 7.

${ }^{220}$ Noordegraaf, "Hybrid Professionalism and Beyond," 189.
} 
mechanised and regulated by organisational controls, are 'valuable', rather than (or alongside) promising that they themselves are personally trustworthy or are part of a trustworthy community. Trust is assured through visibility and through 'proving value', not primarily or only through the fact of the lawyer's intense education, socialisation and professional duties.

Lawyers' core skills and norms of practice (acquired and standardised traditionally through shared education and socialisation) are, in many specialist areas, dramatically changing; lawyers need to be specialists or provide non-legal knowledge as well. Clients are demanding 'holistic' advice, requiring lawyers to understand the client's legal and commercial (and other) needs and, as mentioned above, their sense of 'quality' and related budgetary expectations. In reifying this change, LPM clearly extends the longer-standing discursive change to 'client as sovereign', mapped out in Part II.

Several scholars have shown the hazards or inaccuracies of pitting professionalism and managerialism; in practice, they may be interpreted very similarly and reach consistent outcomes. ${ }^{221}$ In the law context, perhaps enacting the client's best interests based on the client's informed consent - classic features of professional care - should include more fully understanding and empowering them through transparency (managerialism). LPM also seems to offer the possibility for more meaningful, professional authority. By standardising and codifying practices for how to deliver legal services-documenting these processes in artefacts such as workflows, work breakdown structures and Gantt charts-LPM enhances openness and the ability to share professional knowledge. This helps redress a historical power imbalance in the relationship between legal professionals and their clients by providing clients with insights into the steps undertaken by legal professionals to provide their services. With this knowledge, clients are better able to hold their legal professionals to account regarding lawyers' decision-making and performance. $^{222}$ In setting out procedures, LPM claims to result in fewer surprises, more certainty for lawyer and client, and therefore reduced conflicts. The typical complaints made of lawyers involve these 'mundane' things, such as clients being shocked about fees, the lawyer apparently abandoning the client or other communication breakdowns. For LPM practitioners, their approach strengthens the grounds of legitimacy in trust, not simply 'accountability':

LPM ... makes it possible to catch problems as they are happening, not weeks after they've already occurred. It improves communication with clients by being inclusive of the client and making the end-to-end process as transparent as possible. This gives clients an opportunity to have meaningful and contextually relevant discussions with their attorney, greatly increasing the level of trust between them. ${ }^{223}$

LPM, as with project management more broadly, claims to enable truer partnerships and collaboration, with buy-in from everyone and win-win outcomes. ${ }^{224}$ One of the aims of LPM is that lawyers themselves become managers as well, a selfdisciplinary feature we further contemplate below, but meaning that lawyers are given some leeway for how they practise LPM and when it is needed. 225 There is little reason to think that practitioners could not (assuming this is not already taking place) agree on these standards of LPM knowledge and share and refine them among themselves (an aspect of traditional professionalism), without continual reference to an external manager, and that this could improve 'professional' trust, not simply 'service provider' results.

LPM would, however, appear to present serious risks to the cornerstones of that professional trust, specifically to duties of confidentiality and client legal privilege. LPM formally encourages collaboration and sharing of information within legal teams and among teams that include both non-lawyers and lawyers outside the firm, risking confidentiality breaches. LPM's elements of standardisation can help underpin the offshoring and outsourcing of legal service delivery, all of which typically take place online, bringing additional data privacy and protection issues. Moreover, communications not made in confidence, a potential breach of a foundational professional duty, can be fatal to a client's claim of professional privilege. Privilege can attach to communications between an in-house lawyer and their employer, provided that the lawyer is acting in their professional legal capacity, and the communication is made in confidence. ${ }^{226}$ This raises another point: LPM, to the extent that it is a move to make all lawyers managers, might risk that privilege may not apply to communications with an in-house lawyer who is not sufficiently independent or whose non-legal, managerial role has eclipsed their legal one. ${ }^{227}$ In this way, lawyers may be getting 'results' through managerial practices but may be unwittingly chipping away at some of the grounds of their legitimacy as based in trust.

\footnotetext{
${ }^{221}$ See Noordegraaf, "Hybrid Professionalism and Beyond," 187-88 and the sources cited therein.

222 Rogers, "Large Professional Service Firm," 239.

${ }^{223}$ Preston, "Where Rubber Meets the Road."

${ }^{224}$ Lambert, "Is it 'Legal' Project Management."

${ }^{225}$ Noordegraaf, "Hybrid Professionalism and Beyond," 202.

${ }^{226}$ Provided it has, as its dominant purpose, the giving of legal advice or is for use in actual or upcoming litigation.

${ }^{227}$ Gaynor v Chief of the Defence Force (No. 2) (2015) FCA 817; Rich v Harrington (2007) 245 ALR 106.
} 
As another risk, lawyers whose work is now projectified may be reluctant to 'call quits' on a project when that project is no longer serving the client because of the effort invested into the set-up and processes of LPM; or, they may cease a project once 'scope' or the timeframe is reached, even if continuing would be in the client's interests. In this way, lawyers may complete projects on time and to budget, proving greater 'value has been conferred'228 but without necessarily truly acting in the client's best interest. While real collaboration between lawyer and client is a possibility, it can be time-consuming and difficult to manage, particularly with ongoing reporting obligations to the client; even trained project managers find these obligations hard to follow in practice. ${ }^{229}$

As a final point, professional trust was also historically an implicit or notional arrangement between the individual practitioner and society via the professional associations (and/or regulators) who would guarantee the practitioner's ethicality and competence. ${ }^{230}$ Following the broader shifts outlined in Part II, the centring of professionalism in the organisation-now its 'site and source,231_LPM further displaces self-regulatory commitment for external accountability, not simply to the client but to the lawyer's own workplace organisation. Much LPM discourse, for example, is about keeping 'lean' staff, who achieve more, and more predictable 'outcomes'. ${ }^{232}$ All of the transparency benefits for the client can be seen as the firm's greater visibility over performance, including 'delivery' timeframes, ${ }^{233}$ price predictability, ${ }^{234}$ budget management ${ }^{235}$ and reduced 'write-offs'. ${ }^{236}$ But again, there is some slippage. The visibility of milestones and timeframes within a defined plan, for example, could also provide for more satisfying work relationships: colleagues as team members who understand expectations and outcomes, and who can work with higher morale and reduced stress. ${ }^{237}$ Some LPM practitioners promote LPM's team focus as renewing a 'professional' sense of ownership and belonging for partners, too. ${ }^{238}$

\section{C-Values}

LPM's efficiency focus contrasts with the nature of lawyers' traditional professionalism, which has been based on high quality and care. A service ethic, combined with the pursuit of quality and individualised attention, calls for, as Noordegraaf writes, 'time and attention, and forms of professional distance in which technical interventions are applied with an eye on the situation at stake, including its human aspects'. ${ }^{239}$ In contrast, he notes that managerial values focus on service delivery for customers, and efficiency is paramount. ${ }^{240}$ LPM seeks to break down or disaggregate legal matters. The different values at stake, illustrated by the discussion above, have led certain LPM practitioners to predict that fully implemented LPM 'will impose a steep learning curve' on lawyers, requiring them to master 'a whole new vocabulary, suite of IT tools, and procedural protocols'. ${ }^{241}$ They worry that LPM might represent, to lawyers, expertise that is fundamentally in conflict with their own, and in fact undermines their traditional rewards. LPM might be seen as 'an inflexible, mechanistic approach that will devalue their experience and judgment, curtail their discretion, reduce their authority and negatively impact their compensation'. ${ }^{242}$

LPM authors acknowledge, too, that relinquishment over 'quality' is likely to be challenging for lawyers. LPM prioritises efficiency and makes explicit trade-offs between quality and efficiency (in project management, 'quality' is a variable in a triple constraint model of time-cost-quality). Quality is also the client's standard of quality, as the client determines the priorities. Therefore, it challenges lawyers' autonomy and independent judgement on several fronts. Recognising this, LPM practitioners do seek to ensure that LPM is (and is communicated as being) supportive of traditional modes of work and mindful of the uncertainties of professional practice. As Woldow and Richardson assert, 'the forms of project management that are common in the industrial sector, particularly manufacturing, technology, and research, focus on delivering invariant results and producing identical, repeatable outcomes' ${ }^{243}$ They assure lawyers that LPM is different to project management: 'It focuses on

\footnotetext{
228 Woldow, Legal Project Management in One Hour, ix.

${ }^{229}$ Müller, "Governance, Trust and Ethics."

${ }^{230}$ Rogers, "Large Professional Service Firm," 218-19.

231 Rogers, "Large Professional Service Firm," 219, citing Flood, "Re-landscaping," 510.

232 Linton, "Maximising the Benefits."

${ }^{233}$ Lambreth, Legal Project Management, 4-5.

234 Preston, "Where Rubber Meets the Road," 2.

235 Linton, "Maximising the Benefits."

${ }^{236}$ Mullan, "Passing Fad or Here to Stay?" 215.

237 Smith, "5 Examples."

${ }^{238}$ Lambreth, Legal Project Management, 5.

239 Noordegraaf, "Hybrid Professionalism and Beyond," 191, citing Gastelaars, Public Services Under Reconstruction.

240 Noordegraaf, "Hybrid Professionalism and Beyond," 191.

241 Woldow, Legal Project Management in One Hour, xvi.

242 Woldow, Legal Project Management in One Hour, xvi.

243 Woldow, Legal Project Management in One Hour, viii.
} 
delivering value as efficiently as possible under the circumstances' (their emphasis). ${ }^{244}$ The circumstances may be traditional adherence to high standards of quality but in a context of 'well-organized and transparent services' for clients. ${ }^{245}$

Yet, the client may indicate that quality is not their main preference. This might be damaging to lawyers' professional identities - traditionally, lawyers are attached to quality, bespoke work for the client-and expose them to liability risks/negligence. When reducing quality, LPM suggests that lawyers use a disclaimer, but this appears to be a breach of a lawyer's duty to the reputation of the legal profession. Linton argues that quality should be fixed, and the variable is then 'people': cost-time-people. In other words, lawyers should discuss with the client whether they want a senior practitioner (more expensive but higher quality and less time) or a junior practitioner (lower cost but perhaps lower quality and more time). Making these alternatives explicit and returning choice to the client may serve the client best, and potentially promote more affordable justice. Likewise, LPM's flexibility may better encourage innovation in legal services. Its emphasis on teamwork and trust, and playing to the strengths of individuals, might correspondingly encourage a flattening of law firm hierarchies, with the constitution and reconstitution of specialised teams for different projects.

Finally, LPM's elements align with traditional professional 'quality', for instance, enabling timely, accurate, complete and responsive communications from lawyers to clients, and more transparent budgets and costs, provision of which forms part of a lawyer's ethical obligations. In other words, this might simply facilitate an expansive, hybridised form of quality, where, Noordegraaf writes, '[q]uality becomes multifaceted and incorporates organizational aspects and principles that relate case treatment to changing contexts'.246

\section{Part V: Conclusion}

In law, as in other professional organisational contexts, managerial methods have resulted in a reprioritising from autonomy, trust between people, special expertise and high quality. ${ }^{247}$ The focus has shifted to productivity, efficiency, profit and proven 'added value', where, for the professional, 'meeting the demands of the sovereign consumer becomes an imperative', ${ }^{248}$ as well as the performance demands of the professional workplace itself. ${ }^{249}$ This article examined a recently emerged form of managerialism, LPM, as the primary form of projectification within the legal profession. In spotlighting LPM, we sought to outline its origins and what its presence means, or could mean, for legal professionalism.

We suggest that discussion is needed on the precise nature and workings of these new forms of managerialism that are entering legal practice, including LPM. This change is occurring directly through new professional managers and indirectly through lawyers adopting these approaches. Understanding how and to what extent these changes manifest in 'everyday' methods, tools and guides, and how they influence the day-to-day work and primary relationships with clients and colleagues, highlights wider concerns about changing professionalism. These concerns include the elements focused on in this paper: how work is approached and experienced, on what basis professionals are legitimated, and what values are at stake. As professional bodies and law schools have begun to embrace these new methods, this discussion gains additional salience. Without scrutiny, we risk making over-generalised or simplistic assumptions about managerial change, seeing it as a totalising force against traditional professionalism, or conversely, underestimating the prevalence of its discourse and influence. Scholars repeat ideas and expressions from practice parlance such as 'added value' or 'value proposition', often without a full sense of where those phrases come from, and which interpretive schemes ${ }^{250}$ they form a part of -in our case 'value' being central to projectification. LPM also represents not only a management technology, but one with the goal of training lawyers to better manage themselves, and as such, represents an overt instrument of self-discipline. Being a manager of one's own professional work is an autonomy that is already 'inscribed" ${ }^{251}$ with particular expectations. In this vein, LPM supplements other managerial instruments, such as time recording. Yet, LPM is not the 'top-down' management structure seen elsewhere. Though originating from professional managers, it is less centralised than other forms of professional and organisational control, as uptake by lawyers indicates. Furthermore, the source of its methods (whether direct or indirect) is professional management, whose practitioners and associations have additional agendas beyond reshaping 'individual identities around corporate priorities'. ${ }^{252}$ Accordingly, we have taken an expansive look at LPM as a distinctly new form of managerialism.

\footnotetext{
${ }^{244}$ Woldow, Legal Project Management in One Hour, viii.

${ }^{245}$ Noordegraaf, "Hybrid Professionalism and Beyond," 190.

246 Noordegraaf, "Hybrid Professionalism and Beyond," 188.

${ }^{247}$ Noordegraaf, "Hybrid Professionalism and Beyond," 188-190.

${ }^{248}$ Fournier, Boundary Work, 78.

${ }^{249}$ Campbell, "Salaried Lawyers," 110-111.

${ }^{250}$ Pinnington, "Archetype Change," 86, citing Brock, Restructuring the Professional Organization; and Cooper, "Sedimentation and Transformation."

${ }^{251}$ Fournier, "Appeal to Professionalism," 280 and throughout.

252 Muzio, "Introduction: Professions and Organizations," 397.
} 
Our analysis is grounded in an extensive literature tracing the origins of LPM; its roots in, and continuing institutional reliance on project management; its enabling conditions; and the growing number of entities supporting its definition and diffusion. We also drew on original, statistical material to identify numbers of LPM practitioners and those using corresponding skills in legal organisations, showing the extent of LPM's reach and potential reach. These statistics include a relatively low number of LPM practitioners, which, combined with other statistics about uptake, suggest that LPM is in an early phase of adoption. A comparison of the proportions of different roles whose occupiers also identify as lawyers suggests that LPM is most closely allied with lawyers. This fits a picture of LPM developing within law firms as firms train their own cadre of managers internally. Low numbers of LPM practitioners and limited LPM capacity in firms could suggest that some of the perceived threat of (and need for) managerial change may also reflect the advocacy efforts of professional managers making the case for their expertise. Nonetheless, LPM's initial uptake has been among the largest firms and in-house legal teams, which typically have more influence in shaping new professional norms, and legal associations and law schools appear to be supportive.

In terms of professionalism, Noordegraaf's three elements helped to illuminate points of tension and potential areas for concern. These include tensions between unspoken, assumed knowledge regarding processes and the intense and detailed planning of LPM, and the role of honesty and trust at the core of traditional professionalism, as opposed to transparency and 'proven' value. Conversely, Noordegraaf and other writers show that these logics are not always in opposition but can be more or less overlapping and well-aligned. They can even appear the same or act similarly in practice. There is ambiguity in actions, so onlookers may not always be able to distinguish the professional from the managerial, especially when there are similar values, norms, interests and/or objectives involved. ${ }^{253} \mathrm{We}$ saw how this might occur in the addition of transparency to professional care, increasing rather than diminishing trust.

We saw too how projectification might present something different from the two typical options: managerialism or else a move back to or reworking of traditional professionalism. In some ways, it offers a break from the classic ways of working, encouraging flexibility, inclusive teamwork and meaningful collaboration. It might suggest we know too much about the domination of management when projectification might allow for other work practices and therefore require further theorising beyond market and managerial logic. ${ }^{254}$ At the same time, in a professional setting, there remain significant ethical risk areas amid the fluidity (and the structures) of projectification.

Indeed, the analysis of LPM as a management method and discipline shows how it is both mechanistic, yet also fluid and undecided. Professional knowledge and skills have always encompassed a similar tension: visible in their blend of indeterminacy (so that not anyone can do it) and individual judgement (to care for a specific case) on the one hand, and standardisation and technicality (so it is rational and can be shared and coordinated among a community) on the other. ${ }^{255}$ Some of these tensions are merely heightened with managerial expertise being added, presenting more stasis, standardisation and technicality, but also novelty and possibility. ${ }^{256} \mathrm{We}$ need not assume that this is the first time lawyers have dealt with uncertainty or complex expertise. However, when seen as projectification, LPM's dual qualities of control and unpredictability have more meaning as a duality that is essential to its appeal. In other words, projects can encourage and legitimise people working in open, inclusive ways and with less restrained goals, but simultaneously increase monitoring, standardisation and automation. The possibilities are hard to pin down as LPM is still emerging as a profession as shown by our charting of its institutional footing in project management, the way it is practised in-house and by global firms and how its boundaries are far from settled. Our investigation hints at LPM being an ambitious form of managerialism, seeking to challenge the hegemony of other expertise: both legal and other forms of managerialism. At the same time, it needs to serve and be legitimated by its host profession, or more specifically, legal organisations within the wider profession. LPM practitioners must be able to 'bridge' divergent forms of professionalism. ${ }^{257} \mathrm{~A}$ future study might look more closely at the people involved, their multiple goals and targets, the contests about what LPM is and how different it needs to be from other forms of managerialism. We could then learn how the LPM 'professional project' intersects with the 'projects' of law firms. ${ }^{258}$ Moreover, the success of this 'institutional work' 259 would seemingly rely upon LPM practitioners acquiring social positioning among the leaders and partners of legal practices as well as operational managers and, critically, lawyers themselves. ${ }^{260}$ A closer investigation would further reveal how stable LPM is as a hybridity in relation to other elements of lawyers' work, whether LPM respects or

\footnotetext{
253 Olakivi, "Rethinking Managerialism," 21.

${ }^{254}$ Blomgren, "Coping with Contradictions," 78.

255 Abel, The Legal Profession, 9.

${ }^{256}$ Empson, "Institutional Work Dyads," 810, 832-833; Abel, The Legal Profession, 9.

257 Blomgren, "Coping with Contradictions," 79.

${ }^{258}$ Muzio, "Consequences of Defensive Professionalism," 397.

${ }^{259}$ Empson, "Institutional Work Dyads."

${ }^{260}$ Lawrence, "Institutions and Institutional Work;" Lawrence, "Refocusing Institutional Studies;" Empson, "Institutional Work Dyads."
} 
restrains ${ }^{261}$ professional values and practices and what else, beyond what we have detected, is gained and lost through its more widespread diffusion.

\section{Bibliography}

Abel, Richard L. The Legal Profession in England and Wales. New York: Blackwell, 1988.

Ali, Ambreen. "Legal Aid: Big Law Firms are Turning to Project Managers in Response to New Competitive Threats." PM Network 32 (2018): 12-13.

American Bar Association. Report on the Future of Legal Services in the United States. Chicago: American Bar Association, 2016.

Ashurst Advance. "Riding the Winds of Change: The Innovation and Efficiency Agenda in Action." Ashurst, September 15, 2017. https://www.ashurst.com/en/news-and-insights/insights/thought-leadership-from-ashurst-advance/

Association of Corporate Counsel. "Maturity Model for the Operations of a Legal Department." Association of Corporate Counsel, 2020. https://www.acc.com/maturity

Aubry, Monique, Brian Hobbs and Denis Thuillier. "A New Framework for Understanding Organisational Project Management through the PMO.” International Journal of Project Management 25, no 4 (2007): 328-336. https://doi.org/10.1016/j.ijproman.2007.01.004

Australian Institute of Project Management. "Gilbert + Tobin Leads the Way with Industry-First Project Management Accreditation for Lawyers.” Australian Institute of Public Management, March 14, 2018. https://www.aipm.com.au/articles/national/gilbert-tobin-leads-the-way-with-industry-first.aspx

Battilana, Julie, Bernard Leca and Eva Boxenbaum. "How Actors Change Institutions: Towards a Theory of Institutional Entrepreneurship.” The Academy of Management Annals 3, no 1 (2009): 65-107. https://doi.org/10.1080/19416520903053598

Beaton Consulting. Annual Professions Survey (Beyond Blue, 2007).

Bell, Felicity, Justine Rogers and Michael Legg. "Artificial Intelligence and Lawyer Wellbeing." In The Impact of Technology and Innovation on the Wellbeing of the Legal Profession, edited by Michael Legg, Prue Vines and Janet Chan, 239-266. Cambridge: Intersentia, 2020.

Bévort, Frans and Roy Suddaby. "Scripting Professional Identities: How Individuals Make Sense of Contradictory Institutional Logics.” Journal of Professions and Organization 3, no 1 (2016): 17-38. https://doi.org/10.1093/jpo/jov007

Bévort, Frans and Flemming Poufelt. "Human Resource Management in Professional Services Firms: Too Good to be True? Transcending Conflicting Institutional Logics." German Journal of Human Resource Management: Zeitschrift für Personalforschung 29, no 2 (2015): 102-130. https://doi.org/10.1177\%2F239700221502900204

Bleby, Michael. "Legal Services: New Generation of Law Firms Sparks Life into Legal Services." The Proctor 34, no 3 (2014): 60-61.

Blomgren, Maria and Caroline Waks. "Coping with Contradictions: Hybrid Professionals Managing Institutional Complexity." Journal of Professions and Organization 2, no 1 (2015): 78-102. https://doi.org/10.1093/jpo/jou010

Boake, Barbara and Rick Kathuria. Project Management for Lawyers. London: Ark Group, 2011.

Boltanski, Luc and Eve Chiapello. The New Spirit of Capitalism. New York: Verso, 2005.

Boon, Andrew. "The Regulation of Lawyers and Legal Services." In International Perspectives on the Regulation of Lawyers and Legal Services, edited by Andrew Boon, 1-26. Oxford: Bloomsbury, 2017.

Brock, David M, Hüseyin Leblebici and Daniel Muzio. "Understanding Professionals and Their Workplaces: The Mission of the Journal of Professions and Organization." Journal of Professions and Organization 1, no 1 (2014): 1-15.

Brock, David M, Michael Powell and C R Hinings. Restructuring the Professional Organization: Accounting, Health Care and Law. London: Routledge, 1999.

- "Archetypal change and the Professional Service Firm." In Research in Organizational Change and Development (Volume 16), edited by William A Pasmore and Richard W Woodman, 221-251. Bingley: Emerald Group Publishing, 2007.

Burton, William C. Burton's Legal Thesaurus. $5^{\text {th }}$ ed. New York: McGraw-Hill, 2013.

Campbell, Iain and Sara Charlesworth. "Salaried Lawyers and Billable Hours: A New Perspective from the Sociology of Work." International Journal of the Legal Profession 19, no 1 (2012): 89-122. https://doi.org/10.1080/09695958.2012.752151

Canning, Mary and Brendan O'Dwyer. "Regulation and Governance of the Professions: Institutional Work and the Demise of 'Delegated' Self-Regulation of the Accounting Profession." In Professions and Professional Service Firms: Private and

${ }^{261}$ Noordegraaf, "Hybrid Professionalism and Beyond," 192. 
Public Sector Enterprises in the Global Economy, edited by Mike Saks and Daniel Muzio, 157-176. New York: Routledge, 2018.

Carroll, Emily and Steven Vaughan. "Matter Mills and London-Lite Offices: Exploring Forms of the Onshoring of Legal Services in an Age of Globalisation." Legal Ethics 22, no 1-2 (2019): 3-27. https://doi.org/10.1080/1460728x.2019.1693169

Chin, Eric, Graeme Grovum and Matthew Grace. State of Legal Innovation in the Australian Market (Alpha Creates, 2019).

Cicmil, Svetlana. "Understanding Project Management Practice Through Interpretative and Critical Research Perspectives." Project Management Journal 37, no 2 (2006): 27-37.

Clay, Thomas S and Eric A Seeger. Law Firms in Transition: An Altman Weil Flash Survey (Altman Weil, 2018).

Clegg, Stewart and David Courpasson. "Political Hybrids: Tocquevillean Views on Project Organizations." Journal of Management Studies 41, no 4 (2004): 525-547.

Cohen, Alan. "How Six Big Law Firms Get Serious About Legal Project Management." Fulton County Daily Report, August 13, 2012.

Cohen, Mark A. “The Reluctant Rise of Project Management in Law.” LegalMosaic, March 24, 2015. https://www.legalmosaic.com/reluctant-rise-project-management-law/

"COVID-19 will Turbocharge Legal Industry Transformation.” Forbes, March 24, 2020. https://www.forbes.com/sites/markcohen1/2020/03/24/covid-19-will-turbocharge-legal-industrytransformation/\#6f9839fa1195

CommBank. Legal Market Pulse (Commonwealth Bank, 2018).

Cooper, David J, Bob Hinings, Royston Greenwood and John L Brown. "Sedimentation and Transformation in Organizational Change: The Case of Canadian Law Firms.” Organization Studies 17, no 4 (1996): 623-647. https://doi.org/10.1177\%2F017084069601700404

Daly, Anne, Don Fleming and Phil Lewis. "Changes in Solicitors' Firms and Work 1990-2004.” Ethos 204, (2007): $27-29$.

Dombkins, David H. Complex Project Management: Seminal Essays. North Charleston: BookSurge, 2007.

Durkheim, Emile. Professional Ethics and Civic Morals. $2^{\text {nd }}$ ed. Translated by Cornelia Brookfield. New York: Routledge, 1992.

Empson, Laura, Imogen Cleaver and Jeremy Allen. "Managing Partners and Management Professionals: Institutional Work Dyads in Professional Partnerships.” Journal of Management Studies 50, no 5 (2013): 808-844. https://doi.org/10.1111/joms.12025

Evetts, Julia. "Short Note: The Sociology of Professional Groups: New Directions." Current Sociology 54, no 1 (2006): 133143. https://doi.org/10.1177\%2F0011392106057161

Exterro. 2017 Law Firm Benchmarking Report: Emergence of Legal Project Management, Technology and E-discovery Services (Exterro, 2017). https://www.exterro.com/2017-law-firm-benchmarking-report/.

Flood, John. "The Re-Landscaping of the Legal Profession: Large Law Firms and Professional Re-Regulation." Current Sociology 59, no 4 (2011): 507-529. https://doi.org/10.1177\%2F0011392111402725

Fournier, Valerie. “The Appeal to 'Professionalism' as a Disciplinary Mechanism.” The Sociological Review 47, no 2 (1999): 280-307. https://doi.org/10.1111\%2F1467-954X.00173

- "Boundary Work and the (Un)making of the Professions." In Professionalism, Boundaries and the Workplace, edited by Nigel Malin, 67-86. New York: Routledge, 2002.

Frame, J Davidson. The New Project Management: Tools for an Age of Rapid Change, Corporate Reengineering, and Other Business Realities. San Francisco: Jossey-Bass, 1994.

Fred, Mats. "Local Government Projectification in Practice-A Multiple Institutional Logic Perspective." Local Government Studies 46, no 3 (2020): 351-370. https://doi.org/10.1080/03003930.2019.1606799

Friston M. Friston on Costs. 3rd ed. Oxford: Oxford University Press, 2018.

Furlong, Jordan. "The Pivot Generation: How Tomorrow's Lawyers Will Help Build a New and Better Legal Market." Suffolk University Law Review 50, no 3 (2017): 415-439.

Galanter, Mark and William Henderson. "The Elastic Tournament: A Second Transformation of the Big Law Firm." Stanford Law Review 60, (2008): 1867-1929.

Gastelaars, Marja. The Public Services Under Reconstruction. Client Experiences, Professional Practices, Managerial Control. Abingdon: Routledge, 2009.

Gemünden, Hans Georg. "Projectification of Society." Project Management Journal 44, no 3 (2013): 2-4.

Giddings, Jeff and Michael McNamara. "Preparing Future Generations of Lawyers for Legal Practice: What's Supervision Got to Do With It?" University of New South Wales Law Journal 37, no 3 (2014): 1226-1262.

Goodrick, Elizabeth and Trish Reay. "Constellations of Institutional Logics: Changes in the Professional Work of Pharmacists." Work and Occupations 38, no 3 (2011): 372-416. https://doi.org/10.1177\%2F0730888411406824

Greenwood, Royston, C R Hinings and John Brown. "'P2-Form' Strategic Management: Corporate Practices in Professional Partnerships.” Academy of Management Journal 33, no 4 (1990): 725-755. https://doi.org/10.5465/256288 
Greenwood, Royston, David L Deephouse and Stan Xiao Li. "Ownership and Performance of Professional Service Firms." Organization Studies 28, no 2 (2007): 219-238.

Greenwood, Royston, Mia Raynard, Farah Kodeih, Evelyn R Micelotta and Michael Lounsbury. "Institutional Complexity and Organizational Responses." Academy of Management Annals 5, no 1 (2011): 317-371. https://doi.org/10.5465/19416520.2011.590299

Gustafsson, Stefanie, Juani Swart and Nick Kinnie. “"They are Your Testimony”: Professionals, Clients and the Creation of Client Capture During Professional Career Progression.” Organization Studies 39, no 1 (2018): 73-92. https://doi.org/10.1177\%2F0170840617708001

Harris, L. "Future Firm: Why Masterchef Should be on the Menu for Lawyers." ALMJ, July (2012): 26-28.

Hassett, Jim. Legal Project Management, Pricing, and Alternative Fee Arrangements (CreateSpace, 2009).

"Teaching Lawyers How to Manage: Can it Improve the Bottom Line?" The AmLaw Daily, March 18, 2010. https://amlawdaily.typepad.com/amlawdaily/2010/03/hassett.html

Hassett, Jim and Tim Batdorf. The Keys to Legal Project Management Success (LegalBizDev, 2018).

Hazard Jr., Geoffrey C and Ted Schneyer. "Regulatory Controls on Large Law Firms: A Comparative Perspective." Arizona Law Review 44 (2002): 593-608.

Heimerl, April, Holly Hannah, Brittany Ivy, Anne L Christman and Leon Carney. Mini White Paper: Project Management Survey Results (International Legal Technology Association, 2019). http://epubs.iltanet.org/i/1144303-pm19/0?

Henderson, William. "From Big Law to Lean Law." International Review of Law and Economics 38, (2014): 5-16.

Hodgson, Damian. "Disciplining the Professional: The Case of Project Management." Journal of Management Studies 39, no 6 (2002): 803-821. https://doi.org/10.1111/1467-6486.00312

Hodgson, Damian and Svetlana Cicmil. "The Other Side of Projects: The Case for Critical Project Studies.” International Journal of Managing Projects in Business 1, no 1 (2008): 142-152.

Hodgson, Damian and Steve Paton. "Understanding the Professional Project Manager: Cosmopolitans, Locals and Identity Work.” International Journal of Project Management 34, no 2 (2016): 352-364. https://doi.org/10.1016/j.ijproman.2015.03.003

Hodgson, Damian, Mats Fred, Simon Bailey and Patrik Hall. "Introduction.” In The Projectification of the Public Sector, edited by Damian Hodgson, Mats Fred, Simon Bailey and Patrik Hall, 1-19. New York: Routledge, 2019.

Jensen, Anders, Christian Thuesen and Joana Geraldi. "The Projectification of Everything: Projects as a Human Condition." Project Management Journal 47, no 3 (2016): 21-34. https://doi.org/10.1177\%2F875697281604700303

Johnson, Terrence. Professions and Power, London: Routledge, 1972.

Kelk, Norm, Georgina Luscombe, Sharon Medlow and Ian Hickie. Courting the Blues: Attitudes Towards Depression in Australian Law Students and Lawyers (Brain and Mind Institute: University of Sydney, 2009).

Kirkpatrick, Ian and Mirko Noordegraaf. "Organizations and Occupations: Towards Hybrid Professionalism in Professional Service Firms?" In The Oxford Handbook on Professional Service Firms, edited by Laura Empson, Daniel Muzio, Joseph Broschak and Bob Hinings, 92-112. Oxford: Oxford University Press, 2015.

Kirkpatrick, Ian, Stephen Ackroyd and Richard Walker. The New Managerialism and Public Service Professions. Hampshire: Palgrave Macmillan, 2005.

Kiser, Randall. Soft Skills for the Effective Lawyer. Cambridge: Cambridge University Press, 2017.

Konstantinou, Efrosyni. "Professionalism in Project Management: Redefining the Role of the Project Practitioner." Project Management Journal 46, no 2 (2015): 21-35. https://doi.org/10.1002\%2Fpmj.21481

Kuura, Arvi. "Policies for Projectification: Support, Avoid or Let It Be?" Discussions on Estonian Economic Policy (2011): 117-136. http://ssrn.com/abstract=1884204.

Lambert, Greg. “Is it 'Legal' Project Management or just Project Management?” 3 Geeks and a Law Blog, June 9, 2011. https://www.geeklawblog.com/2011/06/elephant-post-is-it-legal-projec.html

Lambreth, Susan Raridon. Legal Project Management: Transforming Legal Services (LawVision Group, 2011).

- RFPs/Surveys Show Clients are Demanding Legal Project Management (LawVision, 2013).

Lambreth, Susan Raridon and David Rueff Jr. Power of Legal Project Management: A Practical Handbook. Chicago: American Bar Association, 2014.

Lambreth, Susan Raridon and Carla Landry. Implementing Legal Project Management: Is There a "Right” Place to Start? (LawVision and LPM Institute, 2015).

Lander, Michael W, Pursey P M A R Heugens and J (Hans) van Oosterhout. "Drift or Alignment? A Configurational Analysis of Law Firms' Ability to Combine Profitability with Professionalism.” Journal of Professions and Organization 4, no 2 (2017): 123-148. https://doi.org/10.1093/jpo/jow011

Larson, Magali. The Rise of Professionalism: A Sociological Analysis. London: University of California Press, 1977.

Law Firm Pricing, "Continuum of Fee Arrangements." Law Firm Pricing, 2020. http://www.patrickonpricing.com/continuum.

Law Institute of Victoria. Disruption, Innovation and Change: The Future of the Legal Profession. (Law Institute of Victoria, 2015). 
Law Society of New South Wales, Future of Law and Innovation in the Profession (Law Society of New South Wales, 2017). Lawrence, Thomas and Roy Suddaby. "Institutions and Institutional Work." In The SAGE Handbook of Organization Studies, edited by Stewart R Clegg, Cynthia Hardy, Thomas B Lawrence and Walter R Nord, 215-254. London: Sage, 2006.

Lawrence, Thomas, Roy Suddaby and Bernard Leca. "Institutional Work: Refocusing Institutional Studies of Organization." Journal of Management Inquiry 20, no 1 (2011): 52-58.

Legal Education and Training Review. Setting Standards: The Future of Legal Services Education and Training Regulation in England and Wales. London: Legal Education and Training Review, 2013.

Legg, Michael. "New Skills for New Lawyers: Responding to Technology and Practice Developments." In The Future of Australian Legal Education: A Collection, edited by Kevin Edmund Lindgren, François Kunc and Michael Coper, 373388. Sydney: Thomson Reuters, 2018.

Levy, Steven B. Legal Project Management: Control Costs, Meet Schedules, Manage Risks, and Maintain Sanity. North Charleston: CreateSpace, 2009.

Lindgren, Monica and Johann Packendorff. "What's New in New Forms of Organizing? On the Construction of Gender in Project-Based Work.” Journal of Management Studies 43, no 4 (2006): 841-866. https://dx.doi.org/10.1111/j.14676486.2006.00613.x

Linton, Therese. Legal Project Management. Chatswood: LexisNexis Butterworths, 2014.

Linton, Therese and Rachel Moore. "Maximising the Benefits of Your Legal Project Management Training Program." Continuing Legal Education Association of Australasia for CPD Professionals Annual Conference, Sydney, Australia, 2017.

Liu, Sida. "Boundaries and Professions: Toward a Processual Theory of Action." Journal of Professions and Organization 5, no 1 (2018): 45-57. https://doi.org/10.1093/jpo/jox012

Lowe, Elle and Charlotte Geddes. "King \& Wood Mallesons Sets New Benchmark in Client Service by Embarking on Australia’s First Legal Project Management Program.” King \& Wood Mallesons, March 28, 2012. https://www.kwm.com/en/au/knowledge/news/king-wood-mallesons-sets-new-benchmark-in-client-service-20120328

Maister, David. "The Trouble with Lawyers.” American Lawyer, April 1, 2006. https://www.law.com/americanlawyer/almID/1143725003462/.

Mautner, Gerlinde. Language and Market Society. London: Routledge, 2013.

McGinnis, John O and Russell G Pearce. "The Great Disruption: How Machine Intelligence Will Transform the Role of Lawyers in the Delivery of Legal Services.” Fordham Law Review 82, no 6 (2014): 3041-3066.

Melbourne Law School and Thomson Reuters. 2018 Australia: State of the Legal Market (Thomson Reuters, 2018). http://insight.thomsonreuters.com.au/resources/resource/state-of-the-australian-legal-market-2018

Mendelsohn, Oliver and Matthew Lippman. "The Emergence of the Corporate Law Firm in Australia." UNSW Law Journal 3, (1979): 78-98.

Midler, Christophe. "Projectification of the Firm: the Renault Case." Scandinavian Journal of Management 11, no 4 (1995): 363-375. https://doi.org/10.1016/0956-5221(95)00035-T

Minsky, Marvin. The Emotion Machine: Commonsense Thinking, Artificial Intelligence, and the Future of the Human Mind. New York: Simon and Schuster, 2006.

Morris, Peter W G, Lynn Crawford, Damian Hodgson, Miles M Shepherd and Janice Thomas. "Exploring the Role of Formal Bodies of Knowledge in Defining a Profession: The Case of Project Management." International Journal of Project Management 24 (2006): 710-721. https://doi.org/10.1016/j.ijproman.2006.09.012

Morris, Peter W G, Jeff Pinto and Jonas Söderlund. "Introduction: Towards the Third Wave of Project Management." In The Oxford Handbook of Project Management, edited by P W G Morris, J Pinto and J Söderlund, 1-12. Oxford: Oxford University Press, 2011.

Moynihan, Catherine J. Taking Charge of Legal Spending-The ACC Value Challenge. (Association of Corporate Council, 2014). https://www.acc.com/resource-library/taking-charge-legal-spending-acc-value-challenge.

Mullan, James. "Legal Project Management: Passing Fad or Here to Stay?” Legal Information Management 12 (2012): 214217. https://doi.org/10.1017/S1472669612000497

Müller, Ralf, Erling S Andersen, Øvind Kvalnes, Jingting Shao, Shankar Sankaran, J Rodney Turner, Christopher Biesenthal, Derek Walker and Siegfried Gudergan. "The Interrelationship of Governance, Trust, and Ethics in Temporary Organizations." Project Management Journal 44, no 4 (2013): 26-44. https://doi.org/10.1002\%2Fpmj.21350

Muzio, Daniel and Stephen Ackroyd. "On the Consequences of Defensive Professionalism: Recent Changes in the Legal Labour Process.” Journal of Law and Society 32, no 4 (2005): 615-642. https://doi.org/10.1111/j.14676478.2005.00340.x

Muzio, Daniel and John Flood. "Entrepreneurship, Managerialism and Professionalism in Action: The Case of the Legal Profession in England and Wales." Handbook of Research on Entrepreneurship in Professional Services. Edward Elgar Publishing, 2012. 
Muzio, Daniel, Damian Hodgson, James Faulconbridge, Jonathan Beaverstock and Sarah Hall. "Towards Corporate Professionalization: The Case of Project Management, Management Consultancy and Executive Search." Current Sociology 59, no 4 (2011): 443-464. https://doi.org/10.1177\%2F0011392111402587

Muzio, Daniel and Ian Kirkpatrick. "Introduction: Professions and organizations-A Conceptual Framework." Current Sociology 59, no 4 (2011): 389-405. https://doi.org/10.1177\%2F0011392111402584

Noordegraaf, Mirko. "From 'Pure' to 'Hybrid' Professionalism: Present-Day Professionalism in Ambiguous Public Domains.” Administration and Society 39, no 6 (2007): 761-785. https://doi.org/10.1177\%2F0095399707304434

. Public Management: Performance, Professionalism and Politics. London: Palgrave Macmillan, 2015.

"Hybrid Professionalism and Beyond: (New) Forms of Public Professionalism in Changing Organizational and Societal Contexts." Journal of Professions and Organization 2, no 2 (2015) 187-206. https://doi.org/10.1093/jpo/jov002

Norman ES, Brotherton SA, Fried RT. Work Breakdown Structures: The Foundation for Project Management Excellence. New York: Wiley, 2008.

Office of the Legal Services Commissioner, 2017-2018 Annual Report (NSW Office of the Legal Services Commissioner, 2018).

Olakivi, Antero and Miira Niska. "Rethinking Managerialism in Professional Work: From Competing Logics to Overlapping Discourses." Journal of Professions and Organization 4, no 1 (2017): 20-35. https://doi.org/10.1093/jpo/jow007

Packendorff, Johann. "The Temporary Society and Its Enemies: Projects from an Individual Perspective." In Beyond Project Management: New Perspectives on the Temporary-Permanent Dilemma, edited by Kerstin Sahlin-Anderson and Anders Soderholm, 39-58. Malmö: Liber, 2002.

Padalkar, Milind and Saji Gopinath. "Six Decades of Project Management Research: Thematic Trends and Future Opportunities." International Journal of Project Management 34, no 7 (2016): 1305-1321. https://doi.org/10.1016/j.ijproman.2016.06.006

Palomaki, Sheri and Felice Wagner. "Legal Project Management from the Inside: 10 Things Law Firm Leaders Need to Know about Implementing Legal Project Management.” Law Practice Today, August 2011. http://ilta.personifycloud.com/webfiles/productfiles/914343/ORG6_10_Things.pdf

Parker, Christine, Adrian Evans, Linda Haller, Suzanne Le Mire and Reid Mortensen. "The Ethical Infrastructure of Legal Practice in Larger Law Firms: Values, Policy and Behaviour." UNSW Law Journal 31, no 1 (2008): 158-188.

Parsons, Talcott. Essays in Sociological Theory. Revised ed. Glencoe: The Free Press, 1954.

Passarella, Gina. "Dechert Puts Its Attorneys Through Project Management Training." The Legal Intelligencer, 2 April 2010.

Paton, Steve and Damian Hodgson. "Project Managers on the Edge: Liminality and Identity in the Management of Technical Work." New Technology, Work and Employment 31, no 1 (2016): 26-40. https://doi.org/10.1111/ntwe.12056

Paton, Steve, Damian Hodgson and Daniel Muzio. "The Price of Corporate Professionalism: Analysing the Corporate Capture of Professions in the UK." New Technology Work and Employment 28, no 3 (2013): 227-240. https://doi.org/10.1111/ntwe.12014

Pinnington, Ashly and Timothy Morris. "Archetype Change in Professional Organizations: Survey Evidence From Large Law Firms." British Journal of Management 14, no 1 (2003): 85-99. https://doi.org/10.1111/1467-8551.00267

Plitz, James P. "Manage What Matters: Project Management Tools to Grow a Legal Practice.” Phoenix Law Review 4, no 1 (2010): 391-434.

Pollack, Julien and Daniel Adler. "Emergent Trends and Passing Fads in Project Management Research: A Scientometric Analysis of Changes in the Field." International Journal of Project Management 33, no 1 (2015): 236-248. https://doi.org/10.1016/j.ijproman.2014.04.011

Preston, Scott and Ryan McClead. "Legal Project Management: Where Rubber Meets the Road." 3 Geeks and a Law Blog, February 27, 2013. https://www.geeklawblog.com/2013/02/lpm-where-rubber-meets-road-part-5-of-5.html

Project Management Institute. A Guide to the Project Management Body of Knowledge (PMBoK Guide). $6^{\text {th }}$ ed. Exton: Project Management Institute, 2017.

Rogers, Justine, Dimity Kingsford Smith and John Chellew. "The Large Professional Service Firm: A New Force in the Regulative Bargain.” University of New South Wales Law Journal 40, no 1 (2017): 218-261.

Rose, Neil. "Wait for ABSs is Over: Tesco Law is Here." The Guardian, April 2, 2012. https://www.theguardian.com/law/2012/apr/02/abs-tesco-law-here

Ruhl, J B. “The Rise of Legal Project Management.” The Young Lawyer 19, no 4 (2015): 6-7.

Runyon, Natalie. "Delta Model Update: The Most Important Area of Lawyer Competency_Personal Effectiveness Skills." Legal Executive Institute, March 21, 2019. https://www.legalexecutiveinstitute.com/delta-model-personal-effectiveness$\underline{\text { skills/ }}$

Salomon, Marc. "Lawyer Personality and Resistance to Change.” Master's Thesis, INSEAD, 2014.

Samuelson, Susan S. "The Organizational Structure of Law Firms: Lessons from Management Theory.” Ohio State Law Journal 51, no 3 (1990): 643-674. 
Shaw, Sara, Gemma Hughes and Trish Greenhalgh. "Standardisation and its Consequences in Health Care: A Case Study of PRINCE2 Project Management Training." In The Projectification of the Public Sector, edited by Damian Hodgson, Mats Fred, Simon Bailey and Patrik Hall, 229-250. New York: Routledge, 2019.

Shinnick, Edward, Fred Bruinsma and Christine Parker. "Aspects of Regulatory Reform in the Legal Profession: Australia, Ireland and the Netherlands." International Journal of the Legal Profession 10, no 3 (2003): 237-267. https://doi.org/10.1080/0969595042000228757

Sjöblom, Stefan. "Administrative Short-Termism-A Non-Issue in Environmental and Regional Governance." Journal of Environmental Policy and Planning 11, no 3 (2009): 165-168. https://doi.org/10.1080/15239080903033747

Sjöblom, Stefan, Karl Löfgren and Sebastian Godenhjelm. "Projectified Politics: Temporary Organisations in a Public Context. Introduction to the Special Issue.” Scandinavian Journal of Public Administration 17, no 2 (2013): 3-11.

Smathers, R Amani. “The 21st-Century T-Shaped Lawyer." Law Practice 40, no 4 (2014): 32-37. http://dashboard.mazsystems.com/webreader/31892

Smith, Antony. "5 Examples of how Legal Project Management can Help Reduce Stress.” Legal Project Management Limited, September 14, 2018. https://legalprojectmanagement.co.uk/5-examples-legal-project-management-reduce-stress/

Solicitors Regulation Authority. "Population of Solicitors in England and Wales." Solicitors Regulation Authority, 2020. https://www.sra.org.uk/sra/how-we-work/reports/statistics/regulated-community-statistics/data/population_solicitors/

Solicitors Regulation Authority. "Statement of Solicitor Competence.” Solicitors Regulation Authority, November $25,2019$. https://www.sra.org.uk/solicitors/resources/cpd/competence-statement/

Sommerlad, Hilary. "Managerialism and the Legal Profession: A New Professional Paradigm." International Journal of the Legal Profession 2, no 2-3 (1995): 159-185.

_. "The Implementation of Quality Initiatives and the New Public Management in the Legal Aid Sector in England and Wales: Bureaucratisation, Stratification and Surveillance." International Journal of the Legal Profession 6, no 3 (1999): 311-343.

'The Commercialisation of Law and the Enterprising Legal Practitioner: Continuity and Change' International Journal of the Legal Profession 18, no 1-2 (2011): 73-108.

Sugarman, David. "Simple Images and Complex Realities: English Lawyers and their Relationship to Business and Politics, 1750-1950." Law and History Review 11, no 2 (1993): 257-301. https://doi.org/10.2307/743616

Susskind, Richard. The End of Lawyers?: Rethinking the Nature of Legal Services. New York: Oxford University Press, 2008.

Toddington, Stuart. "Skills, 'Quality’ and the Ideologies of Managerialism.” Law Teacher 28, no 2 (1994): $243-257$.

Urbis. 2018 National Profile of Solicitors (Urbis, 2018).

Weisbrot, David. "The Changing Face of Australian Legal Practice." The Australian Quarterly 58, no 4 (1986): $426-439$.

Weiss, Debra Cassens. "Lawyer Population 15\% Higher Than 10 Years Ago, New ABA Data Shows." ABA Journal, May 3, 2018. https://www.abajournal.com/news/article/lawyer_population_15 higher than_10_years_ago_new_aba_data_shows

Widdop, Anthony. "Legal Project Management and its Role at the Heart of the Law Firm of the Future." Modern Legal Practice 2, no 1 (2018): 33-37.

Witman, Yolande, Gerhard A C Smid, Pauline L Meurs and Dick L Willems. "Doctor in the Lead: Balancing Between Two Worlds.” Organization 18, no 4 (2010): 477-495. https://doi.org/10.1177\%2F1350508410380762

Woldow, Pamela H and Douglas B Richardson. "Legal Project Management: A Trend at the Tipping Point." The Project Management Hut, May 13, 2010. https://pmhut.com/legal-project-management-a-trend-at-the-tipping-point "Adopting Legal Project Management: Why LPM Is Here to Stay and the Law Firm Manager's Role in Its Evolution." Legal Management 30 (2011): 33-39. Legal Project Management in One Hour for Lawyers. Chicago: American Bar Association, 2014.

\section{Primary Legal Material}

Gaynor v Chief of the Defence Force (No. 2) (2015) FCA 817.

Rich v Harrington (2007) 245 ALR 106. 